\title{
Influence of Calcium and Phosphorus, Lactose, and Salt-to-Moisture Ratio on Cheddar Cheese Quality: Changes in Residual Sugars and Water-Soluble Organic Acids During Ripening
}

\author{
P. Upreti, L. L. McKay, and L. E. Metzger ${ }^{1}$ \\ MN-SD Dairy Foods Research Center, Department of Food Science and Nutrition, \\ University of Minnesota, St. Paul 55108
}

\begin{abstract}
Cheddar cheese ripening involves the conversion of lactose to glucose and galactose or galactose-6-phosphate by starter and nonstarter lactic acid bacteria. Under ideal conditions (i.e., where bacteria grow under no stress of $\mathrm{pH}$, water activity, and salt), these sugars are mainly converted to lactic acid. However, during ripening of cheese, survival and growth of bacteria occurs under the stressed condition of low $\mathrm{pH}$, low water activity, and high salt content. This forces bacteria to use alternate biochemical pathways resulting in production of other organic acids. The objective of this study was to determine if the level and type of organic acids produced during ripening was influenced by calcium $(\mathrm{Ca})$ and phosphorus $(\mathrm{P})$, residual lactose, and salt-to-moisture ratio $(\mathrm{S} / \mathrm{M})$ of cheese. Eight cheeses with 2 levels of $\mathrm{Ca}$ and $\mathrm{P}(0.67$ and $0.47 \%$ vs. 0.53 and $0.39 \%$, respectively), lactose at pressing ( 2.4 vs. $0.78 \%$ ), and $\mathrm{S} / \mathrm{M}(6.4$ vs. $4.8 \%)$ were manufactured. The cheeses were analyzed for organic acids (citric, orotic, pyruvic, lactic, formic, uric, acetic, propanoic, and butyric acids) and residual sugars (lactose, galactose) during $48 \mathrm{wk}$ of ripening using an HPLC-based method. Different factors influenced changes in concentration of residual sugars and organic acids during ripening and are discussed in detail. Our results indicated that the largest decrease in lactose and the largest increase in lactic acid occurred between salting and $d 1$ of ripening. It was interesting to observe that although the lactose content in cheese was influenced by several factors $\mathrm{Ca}$ and $\mathrm{P}$, residual lactose, and $\mathrm{S} / \mathrm{M}$ ), the concentration of lactic acid was influenced only by S/M. More lactic acid was produced in low S/M treatments compared with high S/M treatments. Although surprising for Cheddar cheese, a substantial amount (0.2 to $0.4 \%$ ) of galactose was observed throughout ripening in all treatments. Minor changes in the levels of citric, uric, butyric, and
\end{abstract}

Received August 15, 2005.

Accepted September 26, 2005.

${ }^{1}$ Corresponding author: lmetzger@umn.edu propanoic acids were observed during early ripening, whereas during later ripening, a substantial increase was observed. A gradual decrease in orotic acid and a gradual increase in pyruvic acid content of the cheeses were observed during 12 mo of ripening. In contrast, acetic acid did not show a particular trend, indicating its role as an intermediate in a biochemical pathway, rather than a final product.

Key words: Cheddar cheese, glycolysis, lactose, organic acid

\section{INTRODUCTION}

Glycolysis is an essential biochemical event for the production of fermented milk products, including natural cheeses. It involves the conversion of lactose to constituent sugars or water-soluble organic acids by lactic acid bacteria (LAB). Lactococci (Lactococcus lactis ssp. lactis, and L. lactis ssp. cremoris) are the commonly used starter LAB for Cheddar cheese manufacture because of their ability to convert about $95 \%$ of the fermented sugar to L-lactate (Platt and Foster, 1958). Organisms with greater metabolic diversity can produce additional end-products and may result in undesirable organoleptic characteristics. Although glycolysis is important for a decrease in $\mathrm{pH}$ during Cheddar cheese making, it can also have significant consequences during cheese ripening. About $98 \%$ of the lactose in milk is lost in whey during cheese making, and a relatively small amount of lactose ( 0.3 to $0.6 \% \mathrm{wt} / \mathrm{wt}$ ) stays with cheese (Fox et al., 1990). However, this residual lactose in cheese can be fermented by starter and nonstarter lactic acid bacteria (NSLAB) during ripening, leading to modifications in cheese characteristics.

Cheese manufacture involves acidification and dehydration of milk. This produces a product that has low redox potential, reduced water activity $\left(\mathbf{a}_{\mathbf{w}}\right)$, low $\mathrm{pH}$, high salt, and low lactose concentration. Because of such adverse conditions, starter bacteria cannot grow in cheese during ripening. Unlike starter lactococci, the number of NSLAB increases in cheese during ripening. The dominant NSLAB found in Cheddar cheese include Lactobacillus casei, Lactobacillus plantarum, Lactoba- 
cillus brevis, and occasionally, Streptococcus thermophilus (Swearingen et al., 2001). Different LAB (lactococci, lactobacilli, and $S$. thermophilus) use different systems of lactose transport and catabolism, leading to an accumulation of different intracellular and extracellular products (Hutkins, 2001). It has been well established that the adverse growth conditions in cheese force starter bacteria to use alternate biochemical pathways to survive, which results in the production of a variety of end-products such as acetate, acetoin, $\mathrm{CO}_{2}$, ethanol, formate, and glycerol (Thomas et al., 1979; Liu et al., 1998; Hutkins, 2001; Cárcoba et al., 2004). Similar modifications in biochemical pathways of NSLAB and the formation of other end-products can be expected under conditions that differ between cheese varieties (Crow et al., 2001).

Flavor development in Cheddar cheese might be related to the production and accumulation of different end-products in cheese during ripening. McGugan et al. (1979) found that the flavor intensity of Cheddar cheese was concentrated in the water-soluble fraction of cheese compared with the fat. The results of this study lead to the successful manufacture of reducedfat Cheddar cheese by physically removing fat from aged, full-fat Cheddar cheese (Nelson and Barbano, 2004). A substantial part of the water-soluble fraction of cheese comprises short-chain, water-soluble organic acids and residual sugars that result from glycolysis. Given the importance of glycolytic metabolites in determining cheese flavor, changes in the profile of shortchain, water-soluble organic acids were suggested as the classification parameter of maturity in cheese varieties (Marsili, 1985; de Llano et al., 1996; Califano and Bevilacqua, 1999). Although formation of these compounds is common to all Cheddar cheeses, the type and extent to which the reactions occur might lead to differences between the individual cheeses.

We hypothesize that the extent of lactose metabolism and production of different organic acids in Cheddar cheese during ripening is influenced by certain critical compositional parameters that include $\mathrm{Ca}$ and $\mathrm{P}$, residual lactose, and salt-to-moisture ratio (S/M). Calcium and $\mathrm{P}$ influence the buffering properties of cheese, and hence, affect cheese $\mathrm{pH}$. A decrease in $\mathrm{pH}$ from 6.5 to 5.5 has been demonstrated to decrease lactose consumption and increase the concentration of acetate and formate by L. lactis ssp. lactis (Cárcoba et al., 2004). Controlled incubations of nongrowing cells of $L$. lactis ssp. cremoris at $\mathrm{pH} 6.1,5.3$, and 4.5 indicated that at $\mathrm{pH} 6.1$ and 5.3, $92 \%$ of the fermented lactose accounted for lactic acid, whereas at $\mathrm{pH} 4.5$, only $78 \%$ of the fermented lactose accounted for lactic acid (Liu et al., 1998). Hence, a decrease in $\mathrm{pH}$ led to heterofermentation of lactose. In addition, ionic $\mathrm{Ca}$ is thought to inhibit activity of $\beta$ - galactosidase, a key enzyme for hydrolysis of lactose to glucose and galactose by $S$. thermophilus and lactobacilli (Garman et al., 1996).

Lactic acid bacteria are heterotrophic chemo-organotrophs, and therefore, the amount of substrate present in a medium should influence the growth and the metabolic pathways of LAB. The first evidence of a change in the fermentation behavior of L. lactis from homofermentative to heterofermentative was presented by Thomas et al. (1979). They observed that lactococci, when grown with limited glucose concentration in a chemostat, led to the production of formate, acetate, and ethanol. Similar behavior was observed in nongrowing cells of $L$. lactis when lactose was used as a substrate in limited concentration (Fordyce et al., 1984). On the other hand, the growth of NSLAB under limited or excess levels of residual lactose in cheese is unknown.

Salt-to-moisture ratio influences $\mathrm{a}_{\mathrm{w}}$ of cheese (Marcos et al., 1981), and hence influences growth and metabolic pathways of LAB. Liu et al. (1998) observed that when cells of L. lactis ssp. cremoris were suspended in young cheese curds and $\mathrm{a}_{\mathrm{w}}$ was decreased from 0.99 to 0.87 , heterofermentative metabolism of lactose occurred, and additional accumulation of galactose and formation of certain unknown organic compounds was observed. Bassit et al. (1993) attributed differences in the growth rate with change in $\mathrm{a}_{\mathrm{w}}$ to alterations in lactose active transport or energy-producing systems. These authors also mentioned the possibility of inhibition or activation of certain enzymatic regulation mechanism or modification of membrane permeability with a change in $a_{w}$.

Although the above mentioned studies investigated the influence of one or more factors on glycolysis in LAB, no study, to our knowledge, has examined the influence of these factors in real cheeses. Our study was designed to investigate the use of residual lactose and changes in water-soluble organic acids by concomitant change in $\mathrm{Ca}$ and $\mathrm{P}$, lactose, and $\mathrm{S} / \mathrm{M}$ in cheese.

\section{MATERIALS AND METHODS}

\section{Experimental Design}

Cheese curds with 2 levels (high and low) of $\mathrm{Ca}$ and $\mathrm{P}$, and 2 levels (high and low) of residual lactose were manufactured. The resulting 4 cheese curds were subsequently divided in half and salted at 2 levels (high and low). The manufactured Cheddar cheeses constituted 3 factors at 2 levels and a total of 8 different treatments. The treatments were high $\mathrm{Ca}$ and $\mathrm{P}-$ high lactose-high $\mathrm{S} / \mathrm{M}$ (HHH); high $\mathrm{Ca}$ and $\mathrm{P}-$ high lactose-low $\mathrm{S} / \mathrm{M}$ (HHL); high Ca and P-low lactose-high S/M (HLH); high $\mathrm{Ca}$ and $\mathrm{P}-$ low lactose-low S/M (HLL); low Ca and $\mathrm{P}$-high lactose-high S/M (LHH); low $\mathrm{Ca}$ and $\mathrm{P}-$ high lactose-low S/M (LHL); low Ca and P-low lactose-high 
Table 1. Average chemical composition of cheeses expressed as percentage by weight of cheese (mean of 3 replicates)

\begin{tabular}{lcccccccc}
\hline & \multicolumn{7}{c}{ Treatment $^{1}$} \\
\cline { 2 - 8 } & HHH & HHL & HLH & HLL & LHH & LHL & LLH & LLL \\
\hline Moisture & $32.07^{\mathrm{a}}$ & $33.80^{\mathrm{bc}}$ & $33.07^{\mathrm{ab}}$ & $35.21^{\mathrm{de}}$ & $34.08^{\mathrm{bcd}}$ & $35.94^{\mathrm{e}}$ & $34.39^{\mathrm{sd}}$ & $37.57^{\mathrm{f}}$ \\
Fat & $35.93^{\mathrm{a}}$ & $34.95^{\mathrm{ab}}$ & $35.66^{\mathrm{ab}}$ & $34.75^{\mathrm{abc}}$ & $34.48^{\mathrm{bcd}}$ & $33.62^{\mathrm{cd}}$ & $34.67^{\mathrm{abc}}$ & $33.32^{\mathrm{d}}$ \\
Protein & $26.40^{\mathrm{a}}$ & $25.55^{\mathrm{abc}}$ & $26.02^{\mathrm{ab}}$ & $25.29^{\mathrm{bcd}}$ & $25.1^{\mathrm{cd}}$ & $24.77^{\mathrm{cd}}$ & $25.29^{\mathrm{bcd}}$ & $24.46^{\mathrm{d}}$ \\
Salt & $2.04^{\mathrm{bc}}$ & $1.68^{\mathrm{d}}$ & $2.14^{\mathrm{ab}}$ & $1.73^{\mathrm{cd}}$ & $2.28^{\mathrm{ab}}$ & $1.63^{\mathrm{d}}$ & $2.47^{\mathrm{a}}$ & $1.75^{\mathrm{cd}}$ \\
Salt-to-moisture ratio & $6.37^{\mathrm{a}}$ & $4.98^{\mathrm{b}}$ & $6.48^{\mathrm{a}}$ & $4.92^{\mathrm{b}}$ & $6.71^{\mathrm{a}}$ & $4.53^{\mathrm{b}}$ & $7.17^{\mathrm{a}}$ & $4.65^{\mathrm{b}}$ \\
Lactose (d 1) & $1.52^{\mathrm{a}}$ & $1.35^{\mathrm{c}}$ & $0.32^{\mathrm{de}}$ & $0.11^{\mathrm{e}}$ & $1.64^{\mathrm{ab}}$ & $1.41^{\mathrm{bc}}$ & $0.49^{\mathrm{d}}$ & $0.27^{\mathrm{e}}$ \\
Total Ca & $0.69^{\mathrm{a}}$ & $0.68^{\mathrm{a}}$ & $0.67^{\mathrm{a}}$ & $0.66^{\mathrm{a}}$ & $0.55^{\mathrm{b}}$ & $0.54^{\mathrm{b}}$ & $0.55^{\mathrm{b}}$ & $0.51^{\mathrm{b}}$ \\
Total P & $0.48^{\mathrm{a}}$ & $0.48^{\mathrm{a}}$ & $0.48^{\mathrm{a}}$ & $0.47^{\mathrm{a}}$ & $0.42^{\mathrm{b}}$ & $0.42^{\mathrm{b}}$ & $0.41^{\mathrm{b}}$ & $0.40^{\mathrm{b}}$ \\
\hline
\end{tabular}

${ }^{\mathrm{a}-\mathrm{f}}$ Means in a row with a common superscripts do not differ $(P \geq 0.05)$.

${ }^{1}$ Treatments: $\mathrm{HHH}=$ high $\mathrm{Ca}$ and $\mathrm{P}$, high lactose, and high salt-to-moisture $(\mathrm{S} / \mathrm{M}) ; \mathrm{HHL}=$ high Ca and $\mathrm{P}$, high lactose, and low S/M; HLH = high Ca and P, low lactose, and high S/M; HLL = high Ca and P, low lactose, and low S/M; LHH = low Ca and P, high lactose, and high S/M; LHL = low Ca and P, high lactose, and low S/M; LLH = low Ca and P, low lactose, and high S/M; LLL = low Ca and P, low lactose, and low $\mathrm{S} / \mathrm{M}$.

S/M (LLH); and low $\mathrm{Ca}$ and P-low lactose-low S/M (LLL). A detailed description of the cheese-manufacturing protocols that were followed to obtain the desired cheese composition is discussed in a companion manuscript (Upreti and Metzger, 2006). The composition of the cheeses is shown in Table 1. The cheeses were ripened for $48 \mathrm{wk}$, and changes in residual sugars and water-soluble organic acids were monitored during ripening (cheese curds after salting, d 1, and wk 1, 2, 3, $4,8,16,32$, and 48).

\section{Analysis of Acids and Sugars}

Changes in the concentration of residual sugars and water-soluble organic acids in cheese during ripening were monitored using an HPLC-based method described by Zeppa et al. (2001), with the following modifications.

Sample Preparation. About $5 \mathrm{~g}$ of cheese was thoroughly blended for $90 \mathrm{~s}$ with $10 \mathrm{~mL}$ of $0.013 \mathrm{~N}$ sulfuric acid (at $65^{\circ} \mathrm{C}$ ) using a high-shear Omni mixer-homogenizer (model 17105, Omni International, Waterbury, $\mathrm{CT}$ ). The extract was then centrifuged (IEC HT centrifuge, International Equipment Company, Bedford, MA) at 7,000 $\times \mathrm{g}$ for $10 \mathrm{~min}$. After centrifugation, the samples were held at $4^{\circ} \mathrm{C}$ for 10 min to solidify the top fat layer. The solidified fat layer was removed using a spatula, and the supernatant was filtered through Whatman \#4 filter paper. To remove the soluble peptides present in the filtrate, a $0.5-\mathrm{mL}$ aliquot was poured into a 0.5 $\mathrm{mL}$ Microcon centrifugal filter device with a molecular weight cut-off of 3,000 Da (Millipore Corporation, Bedford, MA). The microfuge tubes were centrifuged (Biofuge 15, Heraeus Sepatech GmbH, Germany) at 14,000 $\times g$ for $20 \mathrm{~min}$. The collected filtrate was vortexed and directly injected into the HPLC system.
HPLC. The HPLC system (AKTA design, Pharmacia Biotech AB, Uppsala, Sweden) consisted of a solvent delivery unit (pump P-900), a 20- $\mu \mathrm{L}$ sample injection loop, a variable wavelength UV/visible detector (UV900), and data processing software (Unicorn version 4.0, Amersham Pharmacia Biotech AB). The system was externally equipped with a refractive index detector (Beckman 156 Refractive Index detector, Beckman, Berkeley, CA), and a column heater (Hot Pocket, thermo Hypersil-Keystone, Bellefonte, PA). A $300 \times 7.8$ $\mathrm{mm}$ i.d. cation exchange column (Aminex HPX-87H) held at $65^{\circ} \mathrm{C}$, with a cation $\mathrm{H}^{+}$microguard cartridge (BioRad Laboratories, Hercules, CA), was used for separation of analytes. Analysis was performed isocratically at $0.8 \mathrm{~mL} / \mathrm{min}$ using $0.013 \mathrm{~N}$ sulfuric acid as the mobile phase. The mobile phase was prepared by diluting reagent-grade sulfuric acid (Fisher Scientific, Fair Lawn, NJ) with distilled water. The separated short-chain, water-soluble organic acids (citric, orotic, pyruvic, lactic, formic, uric, acetic, propanoic, and butanoic acids) were detected using the UV detector set at 210 and 285 $\mathrm{nm}$ (Figure 1). The refractive index detector was used for quantification of sugars (lactose, glucose, and galactose; Figure 1). Glucose was not detected in any cheese sample in our study. The detectors were connected in series, with UV detection at both wavelengths being performed simultaneously, followed by refractive index detection. Identification of analytes was performed based on their retention times with UV and refractive index detectors.

Quantification. Quantification of analytes was based on the external standard method. Lactose (Fisher Scientific), glucose (Fisher Scientific), galactose (Fisher Scientific), citric acid (Sigma-Aldrich, Inc., St. Louis, MO), sodium isocitrate (M.P. Biomedicals, LLC, Aurora, $\mathrm{OH}$ ), orotic acid (Sigma), pyruvic acid (Acros Or- 


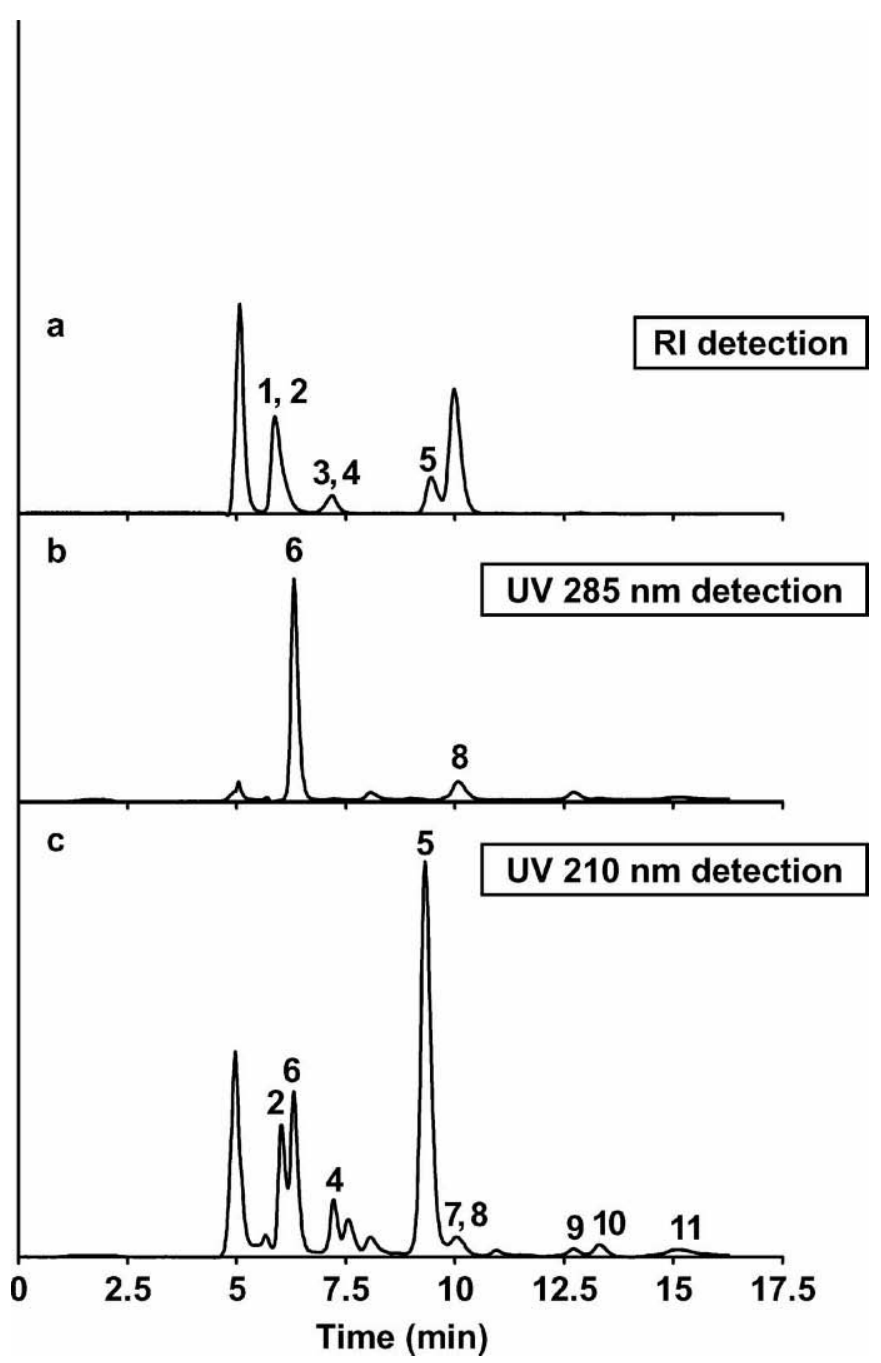

Figure 1. Typical chromatograms of Cheddar cheese for a) refractive index (RI) detection, b) UV detection at $285 \mathrm{~nm}$, and c) UV detection at $210 \mathrm{~nm}$. Sugars and acids detected are represented by numbers; $1=$ lactose, $2=$ citric acid, $3=$ galactose, $4=$ pyruvic acid, $5=$ lactic acid, $6=$ orotic acid, $7=$ formic acid, $8=$ uric acid, $9=$ acetic acid, $10=$ propanoic acid, and $11=$ butanoic acid.

ganics, Fairlawn, NJ), formic acid (Sigma), uric acid (Acros Organics), acetic acid (Sigma), propanoic acid (Sigma), and butanoic acid (Sigma) of highest purity available were used for making stock solutions. The stock solutions were adequately diluted with $0.013 \mathrm{~N}$ sulfuric acid to obtain the desired range of concentration of analytes in the standard solutions to establish the calibration curves. For the analytes that eluted independently, best-fit standard curves were prepared by linear regression of peak area vs. concentration of the analyte (Table 2). However, quantification of coeluting analytes (e.g., citric acid, orotic acid, and lactose) was done using multiple regression equations (Table 2), as suggested by Bouzas et al. (1991).

\section{Statistical Analyses}

A $2 \times 2 \times 2$ factorial model with 3 replications was used for statistical analysis, and changes in the concentration of sugars and acids during ripening were analyzed using a repeated measures design (Table 3). The PROC GLM procedure of SAS, which involved 3 factors (Ca and $\mathrm{P}$, residual lactose, and $\mathrm{S} / \mathrm{M}$ ) as class variables, was used for the data analyses (SAS Institute, 1990). The simple linear and multiple regression equations (Table 2) for estimating the unknown concentrations of given analytes were obtained using PROC REG procedure of SAS (SAS Institute, 1990).

\section{RESULTS AND DISCUSSION}

\section{Change in Lactose Content}

Lactose content was significantly $(P<0.05)$ affected by $\mathrm{Ca}$ and $\mathrm{P}$, lactose, $\mathrm{S} / \mathrm{M}$, time, and the interactions of time $\times$ lactose and time $\times \mathrm{S} / \mathrm{M}$ (Table 3 ). The lactose content decreased in all treatments during ripening (Figure 2a,b). However, the largest decrease in lactose content was from salting the cheese curds to the cheese at $d 1$ (Figure 2a). Relatively small changes in lactose content were observed after $\mathrm{d} 1$, indicating that starter bacteria had minimal ability to metabolize residual lactose in the cheeses after $d 1$. Turner and Thomas (1980) also observed that lactose was fermented by starter bacteria in the first $8 \mathrm{~d}$. Any fermentation thereafter was attributed to NSLAB. Hence, a slight decrease in lactose content observed in cheeses (especially LLL and HLL) during prolonged ripening (Figure $2 \mathrm{~b}$ ) was probably because of NSLAB.

Within different treatments, the lactose content was higher in cheeses with low Ca and P (LHH, LHL, LLH, LLL) vs. high Ca and $\mathrm{P}$ (HHH, HHL, HLH, HLL); high lactose (HHH, HHL, LHH, LHL) vs. low lactose (HLH, HLL, LLH, LLL); and high S/M (HHH, HLH, LHH, LLH) vs. low S/M (HHL, HLL, LHL, LLL). Differences between treatments could be related to dissimilarities in the moisture content of cheeses (Upreti and Metzger, 2006) and its influence on bacterial activity. A similar possibility was hypothesized by Thomas and Pearce (1981). However, they observed weaker correlations between moisture and residual lactose or $\mathrm{pH}$, and concluded that it seems unlikely that moisture, per se, has an important effect. Hence, influence of other factors (Ca and $\mathrm{P}$, residual lactose, and $\mathrm{S} / \mathrm{M}$ ) on lactose metabolism was addressed.

A higher level of residual lactose in low $\mathrm{Ca}$ and $\mathrm{P}$ treatments compared with high $\mathrm{Ca}$ and $\mathrm{P}$ treatments can be attributed to differences in the activity of starter bacteria and differences in buffering properties of these cheeses. Low $\mathrm{Ca}$ and $\mathrm{P}$ treatments had lower $(P<0.05)$ 
Table 2. Retention time (RT) for different analytes, their detection, and calibration curves

\begin{tabular}{|c|c|c|c|c|c|c|}
\hline \multirow[b]{2}{*}{ Analyte } & \multirow[b]{2}{*}{$\mathrm{RT}(\min )$} & \multicolumn{3}{|c|}{ Detection $^{1}$} & \multirow[b]{2}{*}{ Calibration equation } & \multirow[b]{2}{*}{$\mathrm{R}^{2}$} \\
\hline & & 210 & 285 & $\mathrm{RI}$ & & \\
\hline Lactose & 5.8 & & & $x$ & $(0.2396 \times \mathrm{RI}$ area $)-(0.7351 \times$ citric $)+0.02465$ & 0.99 \\
\hline Glucose & 6.8 & & & $\times$ & $(0.3354 \times \mathrm{RI}$ area $)+0.0024$ & 0.99 \\
\hline Galactose & 7.3 & & & $x$ & $(0.255 \times \mathrm{RI}$ area $)+(1.81 \times$ pyruvic $)-0.00191$ & 0.98 \\
\hline Citric acid & 6.3 & $x$ & & $x$ & $(0.0033 \times$ UV 210 area $)-(52.68 \times$ orotic $)+0.00147$ & 0.99 \\
\hline Orotic acid & 6.4 & $x$ & $x$ & & $(0.00008 \times$ UV 285 area $)-0.0000027$ & 0.99 \\
\hline Pyruvic acid & 7.2 & $\times$ & & $\times$ & $(0.000456 \times$ UV 210 area $)-0.00038$ & 0.98 \\
\hline Lactic acid & 9.3 & $x$ & & $x$ & $(0.0046 \times$ UV 210 area $)+0.0037$ & 0.99 \\
\hline Formic acid & 10.0 & $x$ & $\times$ & & $(0.0035 \times$ UV 210 area $)-(37.75 \times$ uric $)(0.00006$ & 0.99 \\
\hline Uric acid & 10.0 & & $x$ & & $(0.000041 \times$ UV 285 area $)+0.00000068$ & 0.99 \\
\hline Acetic acid & 10.9 & $x$ & & & $(0.0058 \times$ UV 210 area $)-0.0009$ & 0.97 \\
\hline Propanoic acid & 12.7 & $x$ & & & $(0.0058 \times$ UV 210 area $)+0.00005$ & 0.99 \\
\hline Butanoic acid & 15.1 & $x$ & & & $(0.0061 \times$ UV 210 area $)-0.0009$ & 0.99 \\
\hline
\end{tabular}

${ }^{1} \mathrm{UV}$ detection at 210 and $285 \mathrm{~nm}$, and refractive index (RI) detection.

${ }^{2}$ The values calculated using the equations were multiplied by dilution factor [(weight of cheese +0.013 $N$ sulfuric acid) $\div$ (weight of cheese)] to get the concentration of analyte in the cheese.

numbers of starter bacteria, and a lower buffering capacity that led to a lower $\mathrm{pH}$, and further suppressed the bacterial activity (Upreti and Metzger, 2006). This led to higher levels of unfermented lactose compared with high $\mathrm{Ca}$ and $\mathrm{P}$ cheeses, in which the number of starter bacteria were higher, and the high buffering supported higher bacterial activity.

In addition, high lactose treatments (HHH, HHL, LHH, LHL) had a higher level of unfermented lactose than low lactose treatments (HLH, HLL, LLH, LLL) throughout ripening. Similar results were observed by other researchers (Huffman and Kristofferson, 1984; Shakeel-Ur-Rehman et al., 2004). However, it is still surprising that the level of lactose was not completely depleted in many treatments during $48 \mathrm{wk}$ of ripening, including a cheese with low lactose (i.e., LLH; Figure $2 b)$. This indicates an influence of other factors, such as $\mathrm{S} / \mathrm{M}$, on lactose metabolism in cheese during ripening.

Cheeses with high S/M had higher levels of unfermented lactose compared with cheeses with low S/M. A similar influence of S/M was observed by Turner and Thomas (1980). Influence of S/M on lactose can be attributed to the differences in bacterial activity due to alteration in $\mathrm{a}_{\mathrm{w}}$ of the cheese (Marcos et al., 1981). Thus, even cheeses with low lactose but high S/M (LLH) had unfermented lactose at $48 \mathrm{wk}$. Only cheeses with low lactose and low S/M (HLL and LLL) revealed complete depletion of lactose. It is worth noting that our results for lactose fermentation are only for $\mathrm{S} / \mathrm{M}$ of 4.5 and 6.5\% (Upreti and Metzger, 2006), and that the low S/ $\mathrm{M}$ treatments correspond to the recommended range of $\mathrm{S} / \mathrm{M}$ in Cheddar cheese (Lawrence et al., 1984). Extensive lactose fermentation can be expected when cheeses have $\mathrm{S} / \mathrm{M}$ of $<4.5 \%$, irrespective of the amount of residual lactose present in cheeses (Shakeel-Ur-Rehman et al., 2004).
In our study, a minimal decrease in residual lactose was observed in cheeses during the first week of ripening, even for low S/M treatments. This could be attributed to the inability of starter to grow and ferment lactose. A low salt tolerance of starter bacteria could lead to such inhibition. Among the commonly used starter bacteria for Cheddar cheese, L. lactis ssp. cremoris is known to have lower salt tolerance than L. lactis ssp. lactis (Sandine et al., 1972). To further investigate why a substantial decrease in residual lactose was not observed in the first few weeks of ripening, even in low S/M treatments, cheeses were analyzed to identify the type of lactococci present. To identify the presence of subspecies cremoris vs. lactis, the cheese dilutions were plated on Bacto-Elliker agar, and incubated at different temperatures ( 30 and $40^{\circ} \mathrm{C}$; data not shown). The presence of a similar number of colonies of starter bacteria in the plates incubated at 30 and $40^{\circ} \mathrm{C}$ indicated that the starter bacteria used were primarily L. lactis ssp. lactis, which can grow at both temperatures (Sandine et al., 1972). The possibility of contamination of these plates with NSLAB (lactobacilli) was checked by morphological (cocci vs. rods) examination of cells from the various colonies using a microscope. These results indicate that even a $\mathrm{S} / \mathrm{M}$ of $4.5 \%$ can inhibit the lactose fermentation by L. lactis ssp. lactis in Cheddar cheese that is ripened at 6 to $8^{\circ} \mathrm{C}$.

\section{Change in Lactic Acid over Time}

The concentration of lactic acid was significantly $(P$ $<0.05)$ affected by $\mathrm{S} / \mathrm{M}$, time, and the interaction of time $\times \mathrm{S} / \mathrm{M}$ (Table 3). The level of lactic acid increased over time $(P<0.05)$ in all treatments (Figure 3a,b). However, the increase in lactic acid from curds to $d$ was larger in low S/M treatments (HHL, HLL, LHL, 
Table 3. Mean squares and probabilities (in parentheses) of changes in sugars or organic acids in Cheddar cheese during storage at 6 to $8^{\circ} \mathrm{C}$ for 48 wk

\begin{tabular}{|c|c|c|c|c|c|c|c|c|c|c|c|c|}
\hline Factors & $\mathrm{df}$ & Lactose & $\begin{array}{l}\text { Lactic } \\
\text { acid }\end{array}$ & Galactose & $\begin{array}{l}\text { Citric } \\
\text { acid }\end{array}$ & $\begin{array}{l}\text { Orotic } \\
\text { acid }\end{array}$ & $\begin{array}{l}\text { Pyruvic } \\
\text { acid }\end{array}$ & $\begin{array}{l}\text { Uric } \\
\text { acid }\end{array}$ & $\begin{array}{l}\text { Formic } \\
\text { acid }\end{array}$ & $\begin{array}{l}\text { Acetic } \\
\text { acid }\end{array}$ & $\begin{array}{l}\text { Propanoic } \\
\text { acid }\end{array}$ & $\begin{array}{l}\text { Butanoic } \\
\text { acid }\end{array}$ \\
\hline \multicolumn{13}{|l|}{ Whole plot } \\
\hline \multirow[b]{2}{*}{$\mathrm{Ca}$ and $\mathrm{P}$} & & $1.51 *$ & 0.018 & $0.0248^{*}$ & $0.072^{*}$ & $5.2 \times 10^{-5 *}$ & $1.3 \times 10^{-5}$ & $1.44 \times 10^{-7}$ & $7.0 \times 10^{-5}$ & $36.0 \times 10^{-5 *}$ & $2.0 \times 10^{-4}$ & $0.073^{*}$ \\
\hline & 1 & $\begin{array}{r}(<0.01) \\
83.40^{*}\end{array}$ & $\begin{array}{r}(0.60) \\
0.124\end{array}$ & $\begin{array}{l}(0.04) \\
0.0035\end{array}$ & $\begin{array}{r}(<0.01) \\
0.04^{*}\end{array}$ & $\begin{array}{l}(<0.01) \\
\quad 1.7 \times 10^{-5 *}\end{array}$ & $\begin{array}{l}(0.63) \\
0.27 \times 10^{-5}\end{array}$ & $\begin{array}{l}(0.22) \\
10.1 \times 10^{-7 *}\end{array}$ & $\begin{array}{l}(0.40) \\
270.0 \times 10^{-5 *}\end{array}$ & $\begin{array}{l}(<0.01) \\
0.6 \times 10^{-5}\end{array}$ & $\begin{array}{l}(0.57) \\
6.8 \times 10^{-4}\end{array}$ & $\begin{array}{l}(<0.01) \\
0.008^{*}\end{array}$ \\
\hline \multirow[t]{2}{*}{ Lactose (L) } & 1 & $(<0.01)$ & $(0.18)$ & $(0.41)$ & $(<0.01)$ & $(<0.01)$ & $(0.82)$ & $(<0.01)$ & $(<0.01)$ & $(0.63)$ & $(0.30)$ & $(<0.01)$ \\
\hline & & $4.05^{*}$ & $8.63^{*}$ & $0.024 *$ & $0.037 *$ & $0.15 \times 10^{-5}$ & $4.0 \times 10^{-5}$ & $7.75 \times 10^{-7 *}$ & $3.8 \times 10^{-5}$ & $117.0 \times 10^{-5 *}$ & $93.0 \times 10^{-4 *}$ & $0.017 *$ \\
\hline \multirow{2}{*}{$\mathrm{S} / \mathrm{M}$} & 1 & $(<0.01)$ & $(<0.01)$ & $(0.04)$ & $(<0.01)$ & $(0.09)$ & $(0.39)$ & $(<0.01)$ & $(0.55)$ & $(<0.01)$ & $(<0.01)$ & $(<0.01)$ \\
\hline & & 0.034 & 0.005 & 0.0043 & 0.0018 & $<0.01 \times 10^{-5}$ & $10.0 \times 10^{-5}$ & $0.14 \times 10^{-7}$ & $18.0 \times 10^{-5}$ & $1.6 \times 10^{-5}$ & $0.2 \times 10^{-4}$ & $0.012^{*}$ \\
\hline \multirow{2}{*}{$(\mathrm{Ca}$ and $\mathrm{P}) \times \mathrm{L}$} & 1 & $(0.39)$ & $(0.78)$ & $(0.36)$ & $(0.36)$ & $(0.93)$ & $(0.19)$ & $(0.69)$ & $(0.20)$ & $(0.41)$ & $(0.86)$ & $(<0.01)$ \\
\hline & & 0.134 & 0.206 & 0.00038 & 0.0031 & $0.02 \times 10^{-5}$ & $1.0 \times 10^{-5}$ & $1.67 \times 10^{-7}$ & $7.0 \times 10^{-5}$ & $9.5 \times 10^{-5}$ & $1.8 \times 10^{-4}$ & 0.00005 \\
\hline \multirow{2}{*}{$\mathrm{L} \times \mathrm{S} / \mathrm{M}$} & 1 & $(0.10)$ & $(0.09)$ & $(0.79)$ & $(0.24)$ & $(0.55)$ & $(0.67)$ & $(0.19)$ & $(0.43)$ & $(0.06)$ & $(0.58)$ & $(0.76)$ \\
\hline & 1 & $\begin{array}{c}0.086 \\
(0.18)\end{array}$ & $\begin{array}{c}0.158 \\
(0.13)\end{array}$ & $\begin{array}{c}0.0054 \\
(0.31)\end{array}$ & $\begin{array}{l}0.0049 \\
(0.14)\end{array}$ & $\begin{array}{l}<0.01 \times 10^{-5} \\
(0.88)\end{array}$ & $\begin{array}{l}31.0 \times 10^{-5 *} \\
(0.03)\end{array}$ & $\begin{array}{l}0.29 \times 10^{-7} \\
(0.58)\end{array}$ & $\begin{array}{l}18.0 \times 10^{-5} \\
(0.20)\end{array}$ & $\begin{array}{l}3.0 \times 10^{-5} \\
(0.24)\end{array}$ & $\begin{array}{l}0.06 \times 10^{-4} \\
(0.92)\end{array}$ & $\begin{array}{l}0.0005 \\
(0.33)\end{array}$ \\
\hline $\begin{array}{l}(\mathrm{Ca} \text { and } \mathrm{P}) \times \mathrm{S} / \mathrm{M} \\
\text { Error }\end{array}$ & 17 & 0.043 & 0.063 & 0.005 & 0.0021 & $0.05 \times 10^{-5}$ & $5.4 \times 10^{-5}$ & $0.90 \times 10^{-7}$ & $9.8 \times 10^{-5}$ & $2.0 \times 10^{-5}$ & $5.9 \times 10^{-4}$ & 0.0005 \\
\hline \multicolumn{13}{|l|}{ Subplot } \\
\hline \multirow{3}{*}{ Time $(\mathrm{T})$} & & $1.55^{*}$ & $0.38^{*}$ & $0.032^{*}$ & $0.176^{*}$ & $3.3 \times 10^{-5 *}$ & $70.0 \times 10^{-5 *}$ & $30.7 \times 10^{-7 *}$ & $52.0 \times 10^{-5 *}$ & $29.0 \times 10^{-5 *}$ & $265.7 \times 10^{-4 *}$ & $0.11^{*}$ \\
\hline & 9 & $(<0.01)$ & $(<0.01)$ & $(<0.01)$ & $(<0.01)$ & $(<0.01)$ & $(<0.01)$ & $(<0.01)$ & $(<0.01)$ & $(<0.01)$ & $(<0.01)$ & $(<0.01)$ \\
\hline & & 0.007 & 0.011 & 0.00052 & $0.014^{*}$ & $0.04 \times 10^{-5 *}$ & $11.0 \times 10^{-5 *}$ & $0.3 \times 10^{-7}$ & $12.0 \times 10^{-5 *}$ & $1.7 \times 10^{-5}$ & $0.88 \times 10^{-4}$ & 0.0015 \\
\hline \multirow{2}{*}{$\mathrm{T} \times(\mathrm{Ca}$ and $\mathrm{P})$} & 9 & $(0.87)$ & $(0.32)$ & $(0.23)$ & $(<0.01)$ & $(<0.01)$ & $(<0.01)$ & $(0.89)$ & $(0.01)$ & $(0.45)$ & $(0.97)$ & $(0.08)$ \\
\hline & & $0.14^{*}$ & 0.010 & 0.00057 & 0.0016 & $3.2 \times 10^{-5 *}$ & $0.9 \times 10^{-5}$ & $1.0 \times 10^{-7}$ & $2.0 \times 10^{-5}$ & $1.9 \times 10^{-5}$ & $4.0 \times 10^{-4}$ & 0.00006 \\
\hline \multirow[t]{2}{*}{$\mathrm{T} \times \mathrm{L}$} & 9 & $(<0.01)$ & $(0.37)$ & $(0.17)$ & $(0.11)$ & $(<0.01)$ & $(0.89)$ & $(0.17)$ & $(0.93)$ & $(0.35)$ & $(0.18)$ & $(0.99)$ \\
\hline & & $0.078 *$ & $0.115^{*}$ & $0.0012 *$ & $0.0076^{*}$ & $0.02 \times 10^{-5}$ & $2.5 \times 10^{-5}$ & $1.0 \times 10^{-7}$ & $3.6 \times 10^{-5}$ & $2.4 \times 10^{-5}$ & $25.0 \times 10^{-4 *}$ & $0.0058^{*}$ \\
\hline \multirow[t]{2}{*}{$\mathrm{T} \times \mathrm{S} / \mathrm{M}$} & 9 & $(<0.01)$ & $(<0.01)$ & $(<0.01)$ & $(<0.01)$ & $(0.07)$ & $(0.26)$ & $(0.19)$ & $(0.69)$ & $(0.18)$ & $(<0.01)$ & $(<0.01)$ \\
\hline & & 0.0086 & 0.015 & 0.00066 & 0.0015 & $0.015 \times 10^{-5}$ & $1.8 \times 10^{-5}$ & $0.2 \times 10^{-7}$ & $3.1 \times 10^{-5}$ & $0.9 \times 10^{-5}$ & $2.9 \times 10^{-4}$ & 0.00059 \\
\hline \multirow[t]{2}{*}{$\mathrm{T} \times(\mathrm{Ca}$ and $\mathrm{P}) \times \mathrm{L}$} & 9 & (0.77) & $(0.12)$ & $(0.09)$ & $(0.14)$ & $(0.24)$ & $(0.52)$ & $(0.97)$ & $(0.76)$ & $(0.86)$ & $(0.41)$ & $(0.72)$ \\
\hline & & 0.0094 & 0.015 & 0.00019 & 0.0004 & $0.05 \times 10^{-5}$ & $0.5 \times 10^{-5}$ & $0.3 \times 10^{-7}$ & $7.5 \times 10^{-5}$ & $1.2 \times 10^{-5}$ & $2.5 \times 10^{-4}$ & 0.0001 \\
\hline \multirow[t]{2}{*}{$\mathrm{T} \times \mathrm{L} \times \mathrm{S} / \mathrm{M}$} & 9 & $(0.72)$ & $(0.12)$ & $(0.88)$ & $(0.95)$ & $(0.93)$ & $(0.98)$ & $(0.92)$ & $(0.87)$ & $(0.69)$ & $(0.54)$ & $(0.99)$ \\
\hline & 9 & $\begin{array}{l}0.0103 \\
(0.66)\end{array}$ & $\begin{array}{c}0.013 \\
(0.22)\end{array}$ & $\begin{array}{l}0.00029 \\
(0.68)\end{array}$ & $\begin{array}{l}0.0014 \\
(0.19)\end{array}$ & $\begin{array}{l}0.04 \times 10 \\
(0.95)\end{array}$ & $\begin{array}{l}1.5 \times 10 \\
(0.67)\end{array}$ & $\begin{array}{l}0.1 \times 1 \\
(0.99)\end{array}$ & $\begin{array}{l}7.5 \times 10 \\
(0.14)\end{array}$ & $\begin{array}{l}1.3 \times 10 \\
(0.66)\end{array}$ & $\begin{array}{l}3.1 \times 10^{-4} \\
(0.36)\end{array}$ & $\begin{array}{l}0.00011 \\
(0.99)\end{array}$ \\
\hline Error & 153 & 0.0137 & 0.0095 & 0.00039 & 0.00097 & $0.011 \times 10^{-5}$ & $0.2 \times 10^{-5}$ & $0.7 \times 10^{-7}$ & $5.2 \times 10^{-5}$ & $1.7 \times 10^{-5}$ & $2.8 \times 10^{-4}$ & 0.00087 \\
\hline
\end{tabular}

*Statistically significant $(P<0.05)$. 


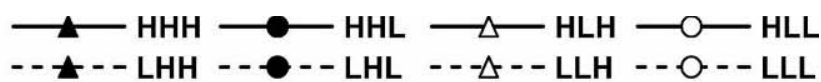

a

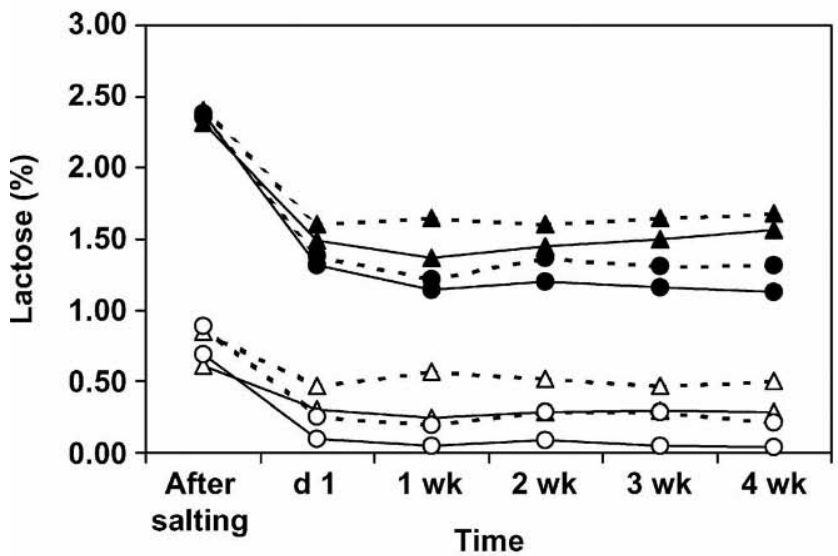

b

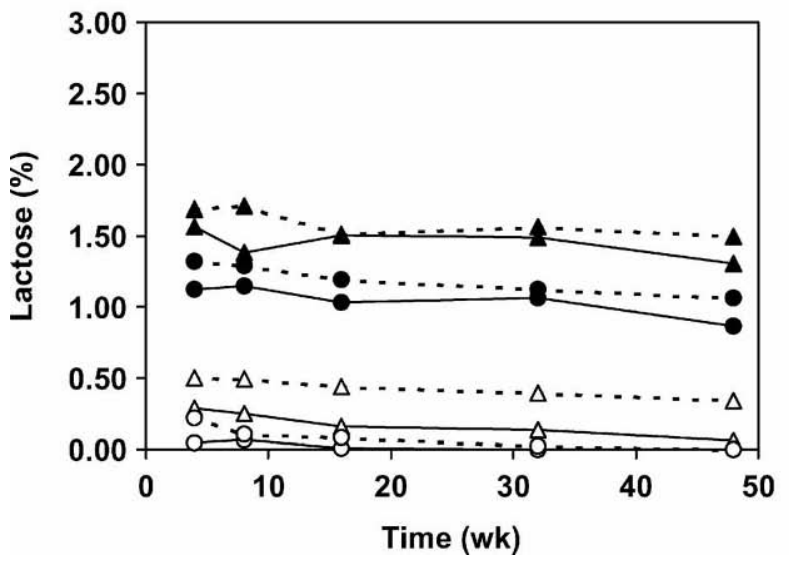

Figure 2. Lactose content of cheese during a) the first month of ripening, and b) over 48 wk of extended ripening. $\mathrm{SEM}=8.84 \times$ $10^{-4}$. Treatments: $\mathrm{HHH}=$ high $\mathrm{Ca}$ and $\mathrm{P}$, high lactose, and high saltto-moisture (S/M); HHL = high $\mathrm{Ca}$ and $\mathrm{P}$, high lactose, and low $\mathrm{S} /$ M; HLH = high Ca and P, low lactose, and high S/M; HLL = high $\mathrm{Ca}$ and $\mathrm{P}$, low lactose, and low $\mathrm{S} / \mathrm{M}$; $\mathrm{LHH}=$ low $\mathrm{Ca}$ and $\mathrm{P}$, high lactose, and high S/M; LHL = low $\mathrm{Ca}$ and $\mathrm{P}$, high lactose, and low $\mathrm{S} / \mathrm{M} ; \mathrm{LLH}=$ low $\mathrm{Ca}$ and $\mathrm{P}$, low lactose, and high $\mathrm{S} / \mathrm{M}$; LLL = low $\mathrm{Ca}$ and $\mathrm{P}$, low lactose, and low S/M.

LLL) compared with high S/M treatments (HHH, HLH, LHH, LLH). This led to higher lactic acid concentration in cheeses during ripening in low $\mathrm{S} / \mathrm{M}$ treatments vs. high S/M treatments (Figure 3).

As shown in Figure 3a, the largest increase in lactic acid was from the cheese curds after salting to the cheese at $d 1$. This increase in lactic acid corresponds to the largest drop in lactose from cheese curds after salting to the cheese at $d 1$. However, the change in lactic acid content during prolonged ripening was comparatively less (Figure $3 \mathrm{~b}$ ), which corresponded to the
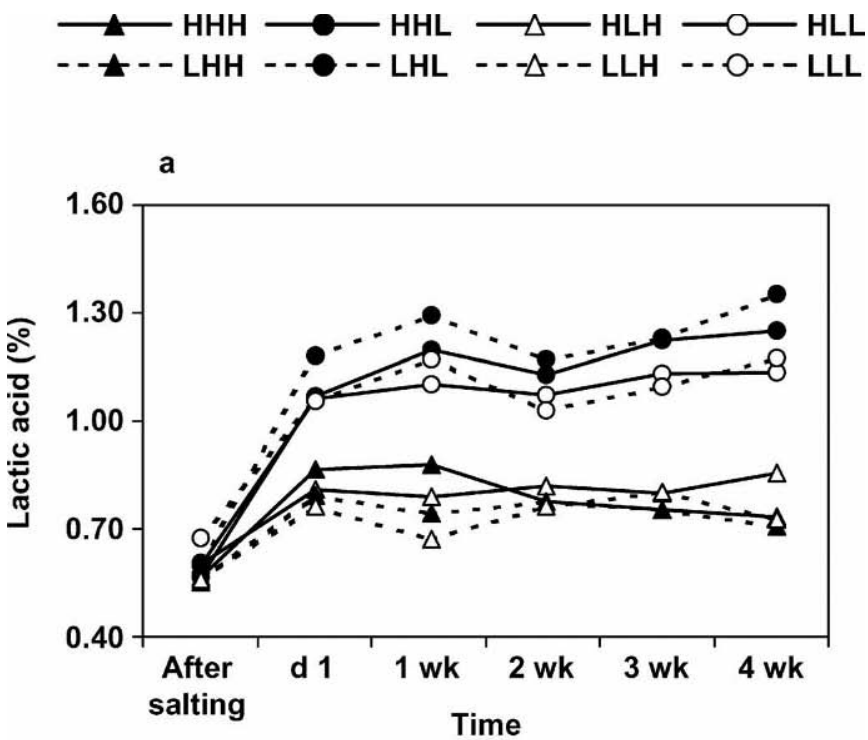

b

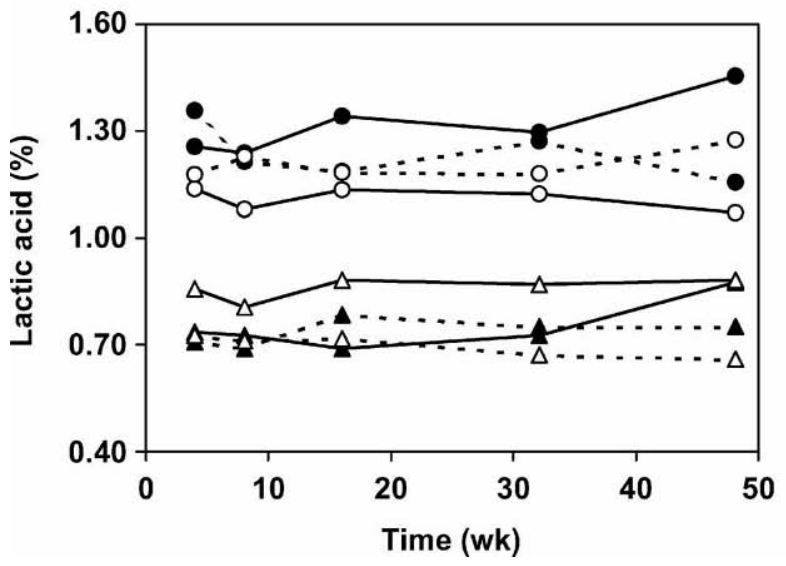

Figure 3. Lactic acid content of cheese during a) the first month of ripening, and b) over 48 wk of extended ripening. $\mathrm{SEM}=1.29 \times$ $10^{-7}$. Treatments: $\mathrm{HHH}=$ high $\mathrm{Ca}$ and $\mathrm{P}$, high lactose, and high saltto-moisture (S/M); HHL = high $\mathrm{Ca}$ and $\mathrm{P}$, high lactose, and low $\mathrm{S} / \mathrm{M}$; $\mathrm{HLH}=$ high $\mathrm{Ca}$ and $\mathrm{P}$, low lactose, and high $\mathrm{S} / \mathrm{M} ; \mathrm{HLL}=$ high $\mathrm{Ca}$ and $\mathrm{P}$, low lactose, and low $\mathrm{S} / \mathrm{M} ; \mathrm{LHH}=$ low $\mathrm{Ca}$ and $\mathrm{P}$, high lactose, and high S/M; LHL = low $\mathrm{Ca}$ and $\mathrm{P}$, high lactose, and low S/M; LLH = low $\mathrm{Ca}$ and $\mathrm{P}$, low lactose, and high $\mathrm{S} / \mathrm{M} ; \mathrm{LLL}=$ low $\mathrm{Ca}$ and $\mathrm{P}$, low lactose, and low S/M.

slight decrease in lactose observed in cheeses during prolonged ripening. St-Gelais et al. (1991) also observed an increase in lactic acid content from $d 1$ to 2 mo of ripening at $4^{\circ} \mathrm{C}$; thereafter, lactic acid content did not change until the end of ripening ( $6 \mathrm{mo}$ ). This illustrates the possibility of heterofermentation during cheese ripening that will occur in order for starter bacteria to survive and NSLAB to grow. Turner and Thomas (1980) observed that residual lactose, which is not fermented during the earlier stages of ripening (first few days), eventually gets used by NSLAB, leading to the forma- 
tion of D-lactate as a major end-product. However, in our study, we did not analyze sugars and acids for their optical isomers; optical isomers cannot be separated using ion-exchange chromatography that was used in this study.

Lactic acid content was higher in treatments with low S/M (HHL, HLL, LHL, LLL) as compared with treatments with high S/M (HHH, HLH, LHH, LLH) (Figure 3). These differences can be explained by the influence of $\mathrm{S} / \mathrm{M}$ on $\mathrm{a}_{\mathrm{w}}$ (Marcos et al., 1981). A reduction of $a_{w}$ leads to a decrease in the growth of LAB and concomitant decrease in lactic acid production (Bassit et al., 1993). We found it intriguing that the decrease in the level of lactose was influenced by several factors, such as $\mathrm{Ca}$ and $\mathrm{P}$, residual lactose, and $\mathrm{S} / \mathrm{M}$, but the production of lactic acid was only influenced by S/M. This indicates that although the amount of lactose is influenced by several factors, the extent to which it is fermented during ripening is influenced only by $\mathrm{S} / \mathrm{M}$.

\section{Change in Galactose over Time}

The galactose content during ripening was significantly $(P<0.05)$ affected by $\mathrm{Ca}$ and $\mathrm{P}, \mathrm{S} / \mathrm{M}$, time, and the interaction of time $\times \mathrm{S} / \mathrm{M}$ (Table 3). A substantial amount $(0.2$ to $0.4 \%)$ of galactose was observed throughout ripening in all treatments. Accumulation of galactose in Cheddar cheese is surprising because of the ability of lactococci to ferment galactose (Hutkins, 2001). However, similar observations were also made by other researchers (Fagen et al., 1952; St-Gelais et al., 1991).

A sudden increase in galactose concentration was observed from the cheese curds to cheeses at $d 1$ (Figure 4a). This increase in galactose content corresponded to a decrease in lactose and an increase in lactic acid during pressing, which resulted from lactococcal activity during this period. However, the sudden stress encountered by lactococci due to the addition of salt might have led to galactose accumulation because of dephosphorylation of galactose-6-phosphate and subsequent excretion from the cells as a mechanism of detoxification in lactococci (Liu et al., 1998). However, a subsequent drop in galactose content was observed from $\mathrm{d} 1$ to wk 1 of ripening (Figure 4a), which could be due to use of galactose by lactococci after they recover from the stress. The increase in galactose thereafter, in certain treatments, during prolonged ripening (Figure $4 \mathrm{~b}$ ) could be due to NSLAB (lactobacilli) metabolism.

In our study, cheeses with low S/M (HHL, HLL, LHL, LLL) had higher levels of galactose compared with cheeses with high S/M (HHH, HLH, LHH, LLH) (Figure $4 a, b)$. These results are in contrast to the results of Fagen et al. (1952), who observed an increase in galac-
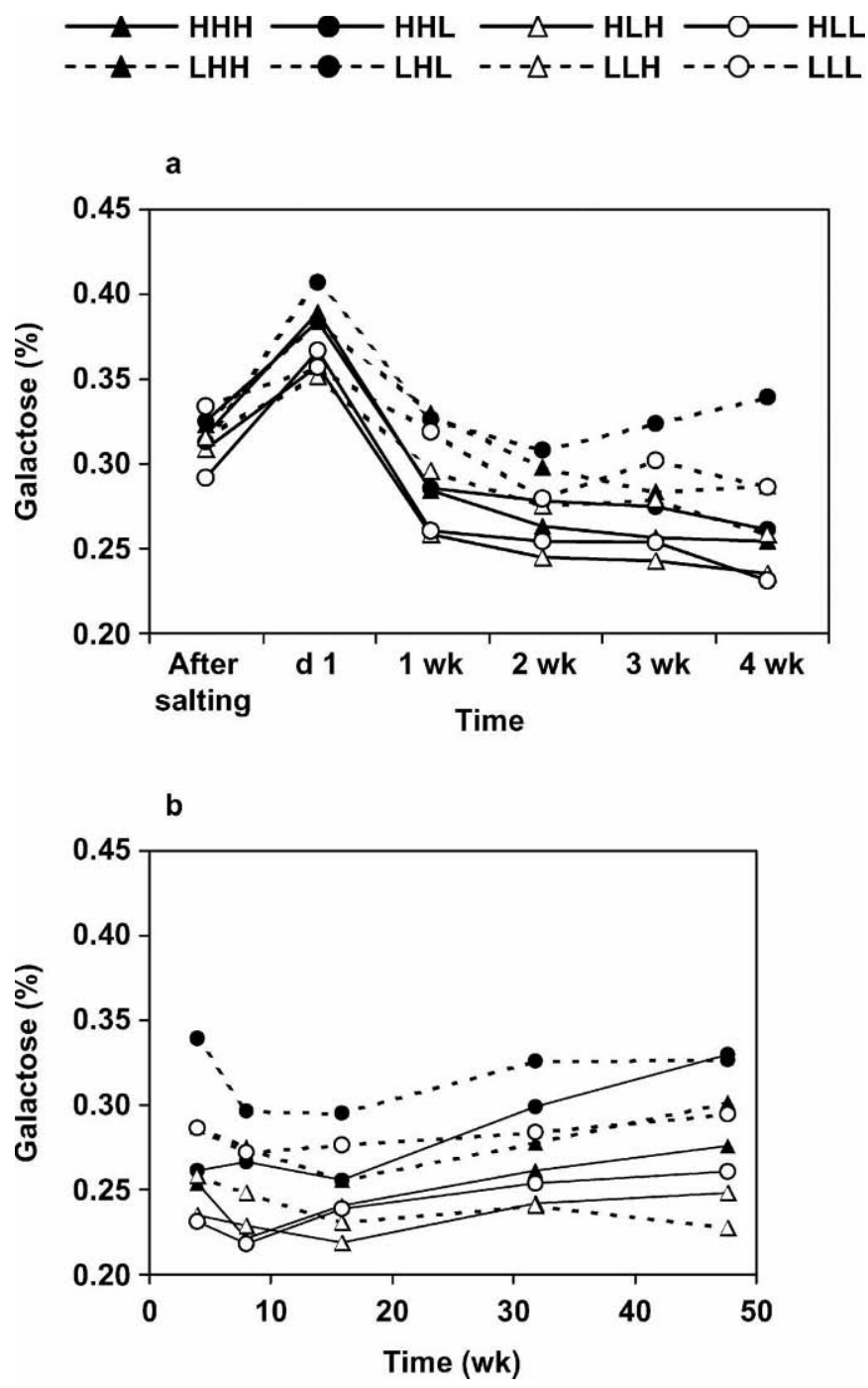

Figure 4. Galactose content of cheese during a) the first month of ripening, and b) over 48 wk of extended ripening. $\mathrm{SEM}=2.52 \times$ $10^{-5}$. Treatments: $\mathrm{HHH}=$ high $\mathrm{Ca}$ and $\mathrm{P}$, high lactose, and high saltto-moisture (S/M); HHL = high $\mathrm{Ca}$ and $\mathrm{P}$, high lactose, and low $\mathrm{S} /$ $\mathrm{M} ; \mathrm{HLH}=$ high $\mathrm{Ca}$ and $\mathrm{P}$, low lactose, and high $\mathrm{S} / \mathrm{M}$; HLL = high $\mathrm{Ca}$ and $\mathrm{P}$, low lactose, and low $\mathrm{S} / \mathrm{M} ; \mathrm{LHH}=$ low $\mathrm{Ca}$ and $\mathrm{P}$, high lactose, and high S/M; LHL = low $\mathrm{Ca}$ and $\mathrm{P}$, high lactose, and low $\mathrm{S} / \mathrm{M} ; \mathrm{LLH}=$ low $\mathrm{Ca}$ and $\mathrm{P}$, low lactose, and high S/M; LLL = low $\mathrm{Ca}$ and $\mathrm{P}$, low lactose, and low $\mathrm{S} / \mathrm{M}$.

tose with higher S/M. We hypothesize that cheeses with low S/M exhibited higher lactose hydrolysis or higher lactococcal activity, which might lead to an increase in galactose. In contrast, cheeses with low levels of $\mathrm{Ca}$ and $\mathrm{P}$ that exhibited lower lactose hydrolysis or lower lactococcal activity were observed to have higher galactose compared with their high $\mathrm{Ca}$ and $\mathrm{P}$ counterparts (LHH vs. HHH, LHL vs. HHL, LLH vs. HLH, LLL vs. HLL; Figure 4a). The reasons for these differences are presently unknown. 


\section{Change in Citric Acid over Time}

The concentration of citric acid in cheeses during ripening was significantly $(P<0.05)$ affected by $\mathrm{Ca}$ and $\mathrm{P}$, lactose, $\mathrm{S} / \mathrm{M}$, time, the interactions of time $\times \mathrm{Ca}$ and $\mathrm{P}$, and time $\times \mathrm{S} / \mathrm{M}$ (Table 3). Within different treatments, citric acid content was higher in cheeses with low $\mathrm{Ca}$ and $\mathrm{P}$ (LHH, LHL, LLH, LLL) vs. high $\mathrm{Ca}$ and $\mathrm{P}$ (HHH, HHL, HLH, HLL); high lactose (HHH, HHL, LHH, LHL) vs. low lactose (HLH, HLL, LLH, LLL); and low S/M (HHL, HLL, LHL, LLL) vs. high S/M (HHH, HLH, LHH, LLH). There was a substantial increase in the citric acid content in all treatments between 4 and 48 wk of ripening. However, the increase in citric acid during ripening (Figure 5b) was larger in low $\mathrm{Ca}$ and $\mathrm{P}$ (LHH, LHL, LLH, LLL) compared with high $\mathrm{Ca}$ and $\mathrm{P}$ (HHH, HHL, HLH, HLL) cheeses; and in low S/M (HHL, HLL, LHL, LLL) vs. high S/M (HHH, HLH, LHH, LLH) cheeses. Reasons for these observed differences between treatments are presently not known.

The production of citric acid in Cheddar cheese is itself surprising, although it has been observed by other researchers as well. McGregor and White (1990) observed a steady increase in citric acid during the ripening of Cheddar cheese. Lues and Bekker (2002) saw a decrease in citric acid over a 40-d period of ripening, followed by a dramatic increase in concentration (with final concentration as high as $0.58 \%$ by weight). These researchers hypothesize that this phenomenon is due to the absence of citrate-fermenting strains of LAB in cheese. This explanation was based on the premise that during Cheddar cheese ripening, citric acid content is influenced by the conversion of citrate to pyruvate, carbon dioxide, and acetic acid by citrate-fermenting microorganisms (Bouzas et al., 1991).

Previous research (Wang et al., 2000) has demonstrated that citrate synthase and aconitase, which are involved in the oxidative branch of the tricarboxylic acid cycle leading to isocitrate biosynthesis, were present in $\mathrm{LAB}$. Therefore, it is possible that LAB can fix carbon dioxide using pyruvate carboxylase and convert pyruvate to oxaloacetate. Lactococcus lactis ssp. lactis and cremoris have been observed to fix carbon dioxide to multiple carbon products (Platt and Foster, 1958) to meet nutritional requirements for carbon dioxide and as a metabolic necessity to prevent normal reoxidation of diphosphopyridine nucleotide. Oxaloacetate, because of the action of citrate synthase, can be further converted to citrate, and depending on the presence of aconitase, it can be converted to isocitrate. However, isocitrate dehydrogenase activity, which further converts isocitrate to $\alpha$-ketoglutarate, was found to be missing. Therefore, formation of $\alpha$-ketoglutarate is prevented
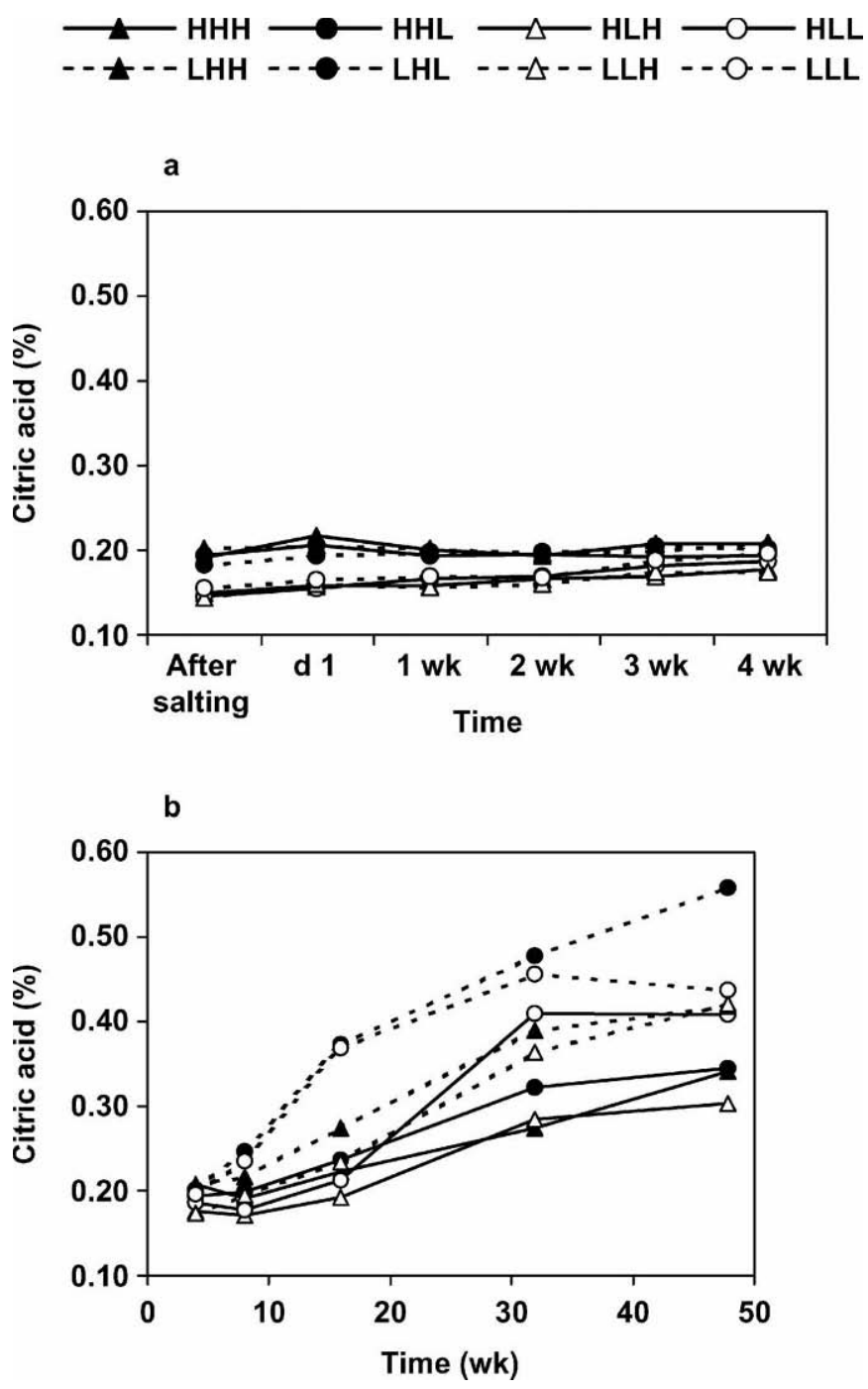

Figure 5. Citric acid content of cheese during a) the first month of ripening, and b) over $48 \mathrm{wk}$ of extended ripening. $\mathrm{SEM}=6.26 \times$ $10^{-5}$. Treatments: $\mathrm{HHH}=$ high $\mathrm{Ca}$ and $\mathrm{P}$, high lactose, and high saltto-moisture (S/M); HHL = high $\mathrm{Ca}$ and $\mathrm{P}$, high lactose, and low $\mathrm{S} / \mathrm{M}$; $\mathrm{HLH}=$ high $\mathrm{Ca}$ and $\mathrm{P}$, low lactose, and high $\mathrm{S} / \mathrm{M} ; \mathrm{HLL}=$ high $\mathrm{Ca}$ and $\mathrm{P}$, low lactose, and low $\mathrm{S} / \mathrm{M} ; \mathrm{LHH}=$ low $\mathrm{Ca}$ and $\mathrm{P}$, high lactose, and high $\mathrm{S} / \mathrm{M} ; \mathrm{LHL}=$ low $\mathrm{Ca}$ and $\mathrm{P}$, high lactose, and low $\mathrm{S} / \mathrm{M} ; \mathrm{LLH}=$ low $\mathrm{Ca}$ and $\mathrm{P}$, low lactose, and high $\mathrm{S} / \mathrm{M} ; \mathrm{LLL}=$ low $\mathrm{Ca}$ and $\mathrm{P}$, low lactose, and low S/M.

and leads to the accumulation of citrate or isocitrate. Under the HPLC conditions used in our study, we could not separate citrate from isocitrate (citrate and isocitrate coelute), and therefore, it is quite possible that the results that we express as citrate can be partially or fully due to isocitrate.

\section{Change in Orotic Acid over Time}

The concentration of orotic acid during ripening was significantly $(P<0.05)$ affected by $\mathrm{Ca}$ and $\mathrm{P}$, lactose, 

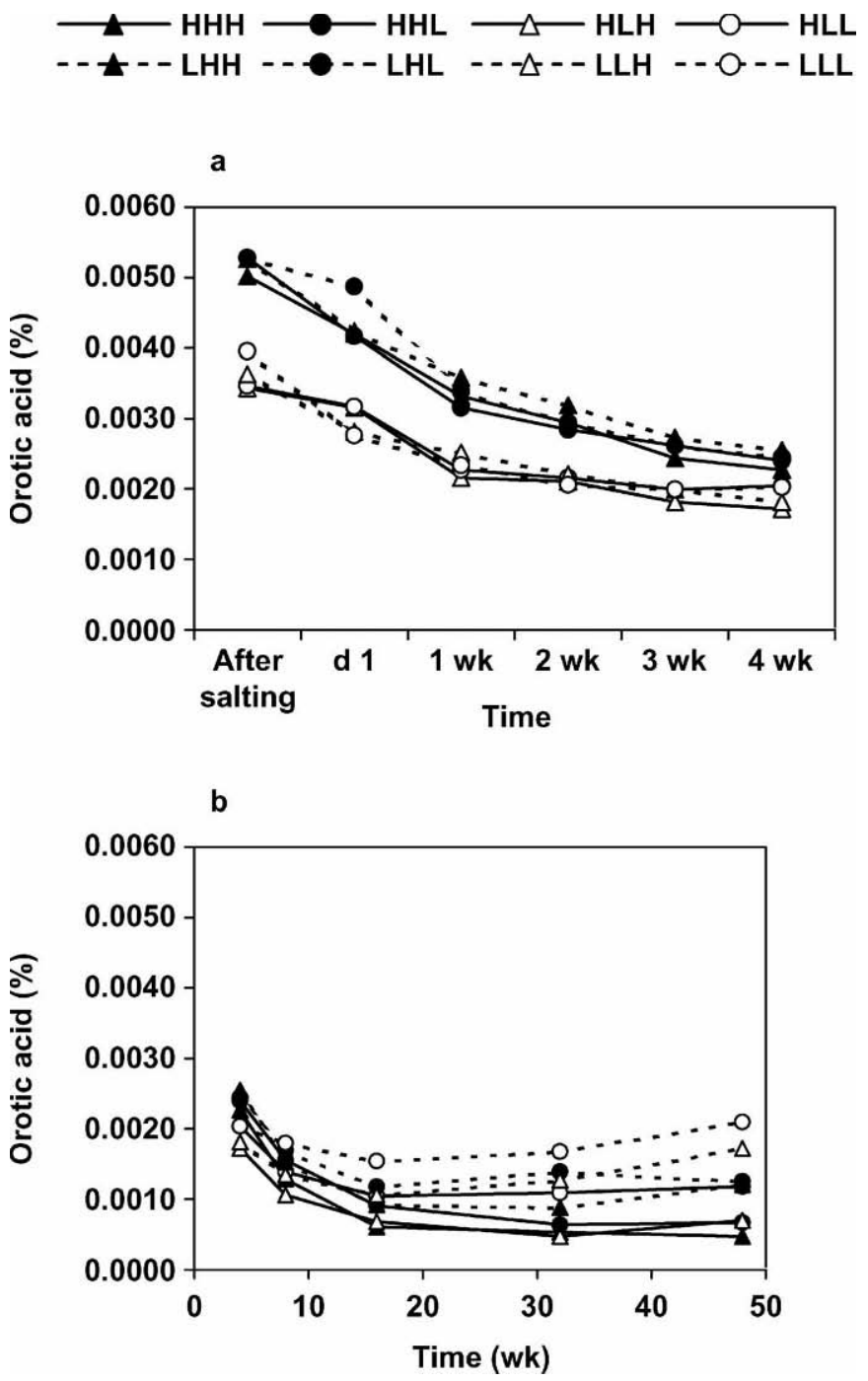

Figure 6. Orotic acid content of cheese during a) the first month of ripening, and b) over 48 wk of extended ripening. SEM = $7.1 \times 10^{-9}$. Treatments: $\mathrm{HHH}=$ high $\mathrm{Ca}$ and $\mathrm{P}$, high lactose, and high salt-to-moisture $(\mathrm{S} / \mathrm{M})$; HHL = high $\mathrm{Ca}$ and $\mathrm{P}$, high lactose, and low $\mathrm{S} / \mathrm{M} ; \mathrm{HLH}=$ high $\mathrm{Ca}$ and $\mathrm{P}$, low lactose, and high $\mathrm{S} / \mathrm{M} ; \mathrm{HLL}=$ high $\mathrm{Ca}$ and $\mathrm{P}$, low lactose, and low $\mathrm{S} / \mathrm{M} ; \mathrm{LHH}=$ low $\mathrm{Ca}$ and $\mathrm{P}$, high lactose, and high $\mathrm{S} / \mathrm{M} ; \mathrm{LHL}=$ low $\mathrm{Ca}$ and $\mathrm{P}$, high lactose, and low $\mathrm{S} / \mathrm{M} ; \mathrm{LLH}=$ low $\mathrm{Ca}$ and $\mathrm{P}$, low lactose, and high $\mathrm{S} / \mathrm{M} ; \mathrm{LLL}=$ low $\mathrm{Ca}$ and $\mathrm{P}$, low lactose, and low $\mathrm{S} / \mathrm{M}$.

time, and the interactions of time $\times \mathrm{Ca}$ and $\mathrm{P}$, and time $\times$ lactose, and marginally $(P=0.07)$ by time $\times \mathrm{S} / \mathrm{M}($ Table $3)$. Orotic acid tends to be more prevalent in milk of ruminant species (Larson and Hegarty, 1979). Therefore, the presence of the initial concentration of orotic acid is largely a result of the milk used for cheesemaking and its retention in cheese, based on the cheesemaking protocols. However, changes in orotic acid during ripening might be related to the metabolic activities of LAB. During early ripening (Figure 6a), differences in orotic acid content in cheeses were more apparent due to lactose, with high lactose cheeses (HHH, HHL, LHH, LHL) having higher orotic acid compared with low lactose cheeses (HLH, HLL, LLH, LLL). These results are similar to those reported by Larson and Hegarty (1979) who noticed that washing of the curds to remove soluble whey solids reduced the orotic acid content of cheese. In our study, washing of curds was involved in manufacturing of cheeses with low lactose (Upreti and Metzger, 2006) and therefore, lowered the orotic acid content in these treatments.

The orotic acid content decreased substantially until 16 wk of ripening (Figure 6), after which a minimal decrease was apparent. A decrease in orotic acid during ripening could be due to the consumption of this acid as a growth factor by LAB (de Llano et al., 1996). This rate of decrease was larger in the high lactose treatments (HHH, HHL, LHH, LHL) than in the low lactose treatments (HLH, HLL, LLH, LLL). Moreover, cheeses with high $\mathrm{Ca}$ and $\mathrm{P}$ showed a higher $(P<0.05)$ rate of decrease in orotic acid content compared with low $\mathrm{Ca}$ and $\mathrm{P}$ cheeses, which eventually led to a lower orotic acid content in high $\mathrm{Ca}$ and $\mathrm{P}$ cheeses (Figure 6b).

\section{Change in Pyruvic Acid over Time}

The pyruvic acid concentration during ripening was significantly $(P<0.05)$ affected by time and the interactions of time $\times \mathrm{Ca}$ and $\mathrm{P}$, and $\mathrm{Ca}$ and $\mathrm{P} \times \mathrm{S} / \mathrm{M}$ (Table 3 ). A sudden increase in pyruvic acid concentration from salting to $\mathrm{d} 1$, and then a decrease from $\mathrm{d} 1$ to $\mathrm{wk}$ 1 was observed (Figure 7a). The change in pyruvic acid content did not show any definite trend at initial stages of ripening (Figure 7a); however, during the later stages of ripening (Figure 7b), cheeses with high $\mathrm{Ca}$ and $\mathrm{P}$ (HHH, HHL, HLH, HLL) exhibited a larger increase in pyruvic acid concentration compared with cheeses with low $\mathrm{Ca}$ and $\mathrm{P}$ (LHH, LHL, LLH, LLL). Furthermore, at high $\mathrm{Ca}$ and $\mathrm{P}$ level, cheeses with low S/M (HHL, HLL) had higher pyruvic acid content compared with high S/M cheeses (HHH, HLH), whereas at low $\mathrm{Ca}$ and $\mathrm{P}$ levels, high S/M cheeses (LHH, LLH) had higher pyruvic acid compared with low S/M cheeses (LHL, LLL) (Figure 7b).

Although a continuous increase in pyruvic acid up to $15 \mathrm{~d}$ of ripening was observed by de Llano et al. (1996), Akalin et al. (2002) observed a decrease in pyruvic acid during aging except between the first and third month. A reason for such differences could be that pyruvate is a key intermediate in sugar metabolism and is readily formed through the glycolytic pathway, and can also act as substrate for several metabolic reactions (Hutkins, 2001). However, for our study, the reasons behind the observed differences in pyruvic acid content between the treatments are presently unknown. 

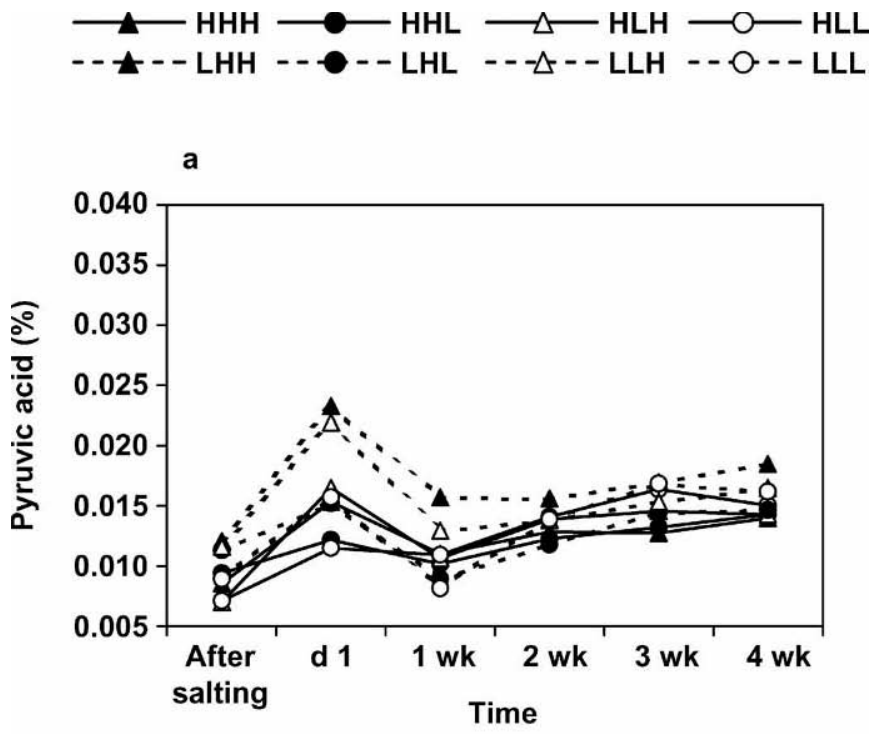

b

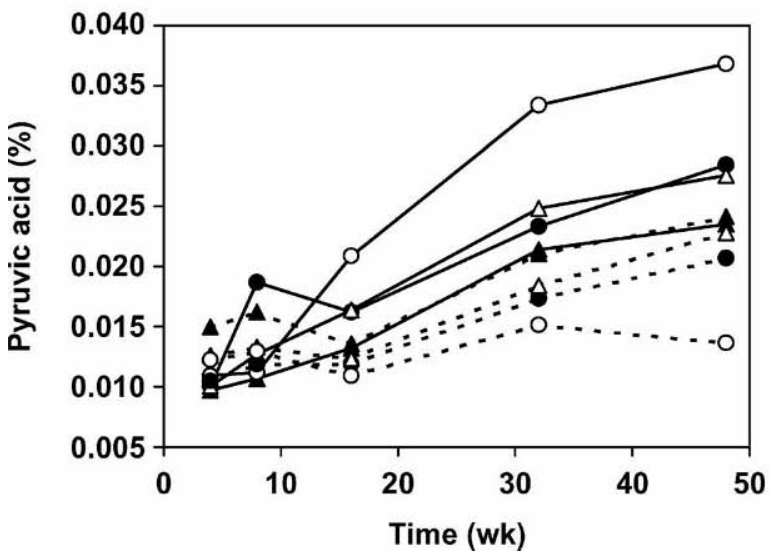

Figure 7. Pyruvic acid content of cheese during a) the first month of ripening, and b) over 48 wk of extended ripening. SEM $=1.29 \times$ $10^{-7}$. Treatments: $\mathrm{HHH}=$ high $\mathrm{Ca}$ and $\mathrm{P}$, high lactose, and high saltto-moisture (S/M); HHL = high $\mathrm{Ca}$ and $\mathrm{P}$, high lactose, and low $\mathrm{S} / \mathrm{M}$; $\mathrm{HLH}=$ high $\mathrm{Ca}$ and $\mathrm{P}$, low lactose, and high S/M; HLL = high $\mathrm{Ca}$ and $\mathrm{P}$, low lactose, and low $\mathrm{S} / \mathrm{M} ; \mathrm{LHH}=$ low $\mathrm{Ca}$ and $\mathrm{P}$, high lactose, and high S/M; LHL = low $\mathrm{Ca}$ and $\mathrm{P}$, high lactose, and low S/M; LLH = low $\mathrm{Ca}$ and $\mathrm{P}$, low lactose, and high $\mathrm{S} / \mathrm{M}$; LLL = low $\mathrm{Ca}$ and $\mathrm{P}$, low lactose, and low $\mathrm{S} / \mathrm{M}$.

\section{Change in Uric Acid over Time}

The uric acid content during ripening was significantly $(P<0.05)$ affected by lactose, $\mathrm{S} / \mathrm{M}$, and time (Table 3). A reduction in uric acid content from $\mathrm{d} 1$ to wk 1 was observed (Figure 8a). However, after $3 \mathrm{wk}$, an increase in uric acid concentration until 48 wk was observed (Figure 8b). According to Akalin et al. (2002), uric acid content remained constant between the first and sixth months, after which it showed a sharp increase, with the highest uric acid content found at the end of ripening. In our study, cheeses with high lactose

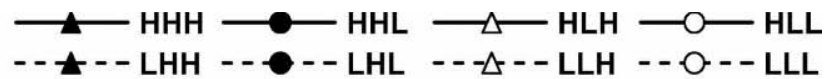

a

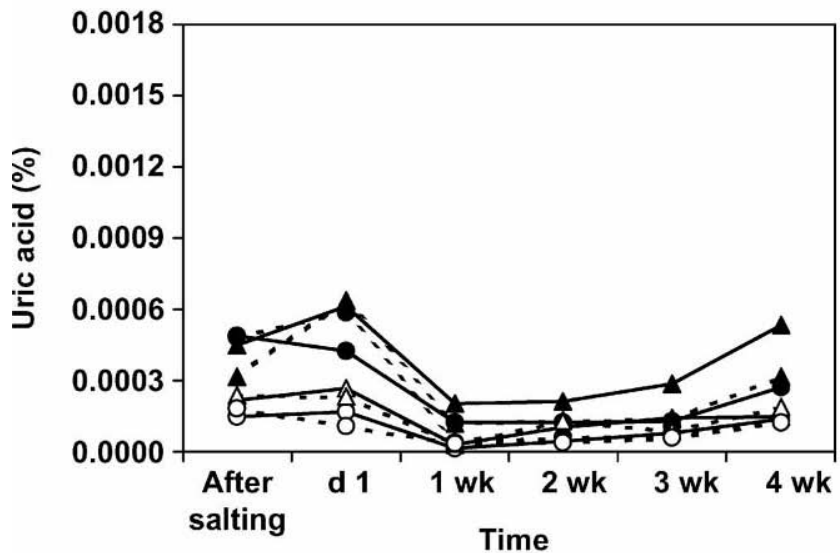

b

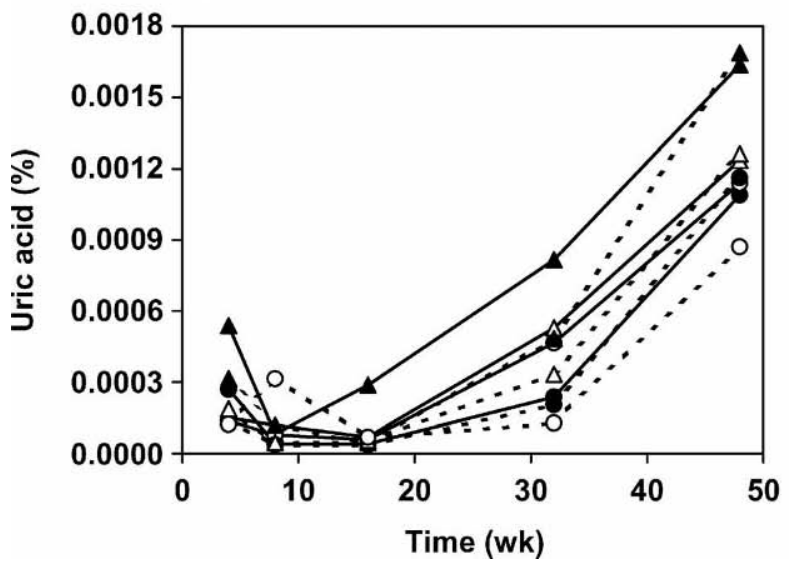

Figure 8. Uric acid content of cheese during a) the first month of ripening, and b) over 48 wk of extended ripening. SEM $=4.52 \times$ $10^{-9}$. Treatments: $\mathrm{HHH}=$ high $\mathrm{Ca}$ and $\mathrm{P}$, high lactose, and high saltto-moisture (S/M); HHL = high $\mathrm{Ca}$ and $\mathrm{P}$, high lactose, and low $\mathrm{S} / \mathrm{M}$; $\mathrm{HLH}=$ high $\mathrm{Ca}$ and $\mathrm{P}$, low lactose, and high $\mathrm{S} / \mathrm{M} ; \mathrm{HLL}=$ high $\mathrm{Ca}$ and $\mathrm{P}$, low lactose, and low $\mathrm{S} / \mathrm{M} ; \mathrm{LHH}=$ low $\mathrm{Ca}$ and $\mathrm{P}$, high lactose, and high $\mathrm{S} / \mathrm{M} ; \mathrm{LHL}=$ low $\mathrm{Ca}$ and $\mathrm{P}$, high lactose, and low $\mathrm{S} / \mathrm{M} ; \mathrm{LLH}=$ low $\mathrm{Ca}$ and $\mathrm{P}$, low lactose, and high $\mathrm{S} / \mathrm{M}$; LLL = low $\mathrm{Ca}$ and $\mathrm{P}$, low lactose, and low S/M.

(HHH, HHL, LHH, LHL) had higher uric acid compared with the corresponding treatments with low lactose (HLH, HLL, LLH, LLL; Figure 8). Moreover, cheeses with high S/M (HHH, HLH, LHH, LLH) had higher uric acid compared with cheeses with low S/M (HHL, HLL, LHL, LLL). A 30- to 50-fold increase in uric acid content after $48 \mathrm{wk}$ of ripening was observed in all treatments (Figure 8).

\section{Change in Formic Acid over Time}

The concentration of formic acid during ripening was significantly $(P<0.05)$ influenced by lactose, time, and 


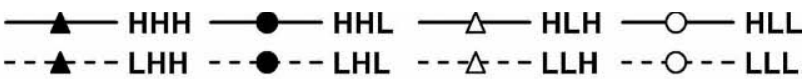

a
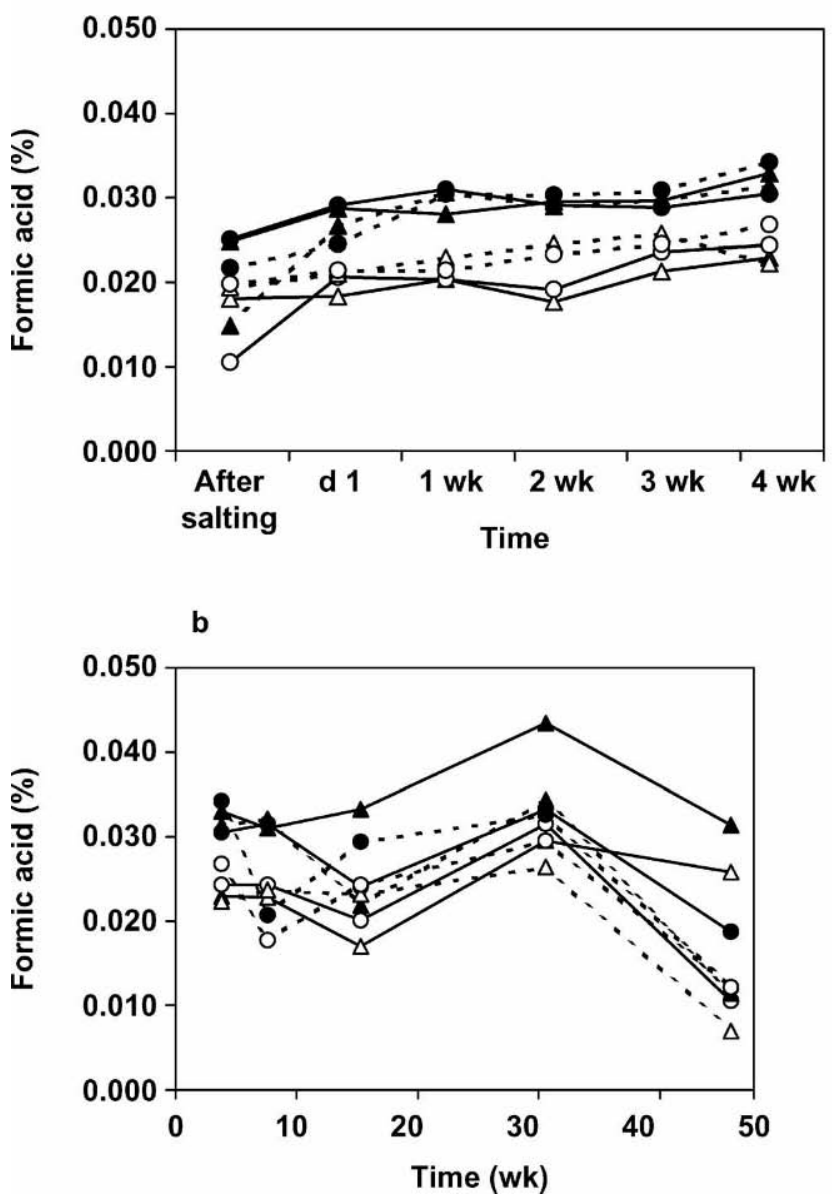

Figure 9. Formic acid content of cheese during a) the first month of ripening, and b) over 48 wk of extended ripening. $\mathrm{SEM}=3.36 \times$ $10^{-6}$. Treatments: $\mathrm{HHH}=$ high $\mathrm{Ca}$ and $\mathrm{P}$, high lactose, and high saltto-moisture (S/M); HHL = high $\mathrm{Ca}$ and $\mathrm{P}$, high lactose, and low $\mathrm{S} /$ $\mathrm{M} ; \mathrm{HLH}=$ high $\mathrm{Ca}$ and $\mathrm{P}$, low lactose, and high $\mathrm{S} / \mathrm{M} ; \mathrm{HLL}=$ high $\mathrm{Ca}$ and $\mathrm{P}$, low lactose, and low $\mathrm{S} / \mathrm{M} ; \mathrm{LHH}=$ low $\mathrm{Ca}$ and $\mathrm{P}$, high lactose, and high $\mathrm{S} / \mathrm{M} ; \mathrm{LHL}=$ low $\mathrm{Ca}$ and $\mathrm{P}$, high lactose, and low $\mathrm{S} / \mathrm{M} ; \mathrm{LLH}=$ low $\mathrm{Ca}$ and $\mathrm{P}$, low lactose, and high $\mathrm{S} / \mathrm{M} ; \mathrm{LLL}=$ low $\mathrm{Ca}$ and $\mathrm{P}$, low lactose, and low S/M.

the interaction of time $\times \mathrm{Ca}$ and $\mathrm{P}$ (Table 3). Formic acid content was higher in the high lactose cheeses (HHH, HHL, LHH, LHL) compared with the low lactose cheeses (HLH, HLL, LLH, LLL), which was more apparent in the earlier stages of ripening (Figure 9a). There were minimal changes in formic acid until $32 \mathrm{wk}$ of ripening, after which there was a sudden drop in formic acid in all the treatments (Figure 9b). According to Akalin et al. (2002), in pickled white cheeses, formic acid was formed during the first month of ripening, increased in the second month, and then remained con- stant until 12 mo of ripening. A similar trend for formic acid in the beginning followed by no substantial change was also observed by Califano and Bevilacqua (1999) for Mozzarella cheese.

\section{Change in Acetic Acid over Time}

The acetic acid concentration during ripening was significantly $(P<0.05)$ affected by $\mathrm{Ca}$ and $\mathrm{P}, \mathrm{S} / \mathrm{M}$, and time (Table 3). No particular trend for the change in acetic acid was observed, although the level of acetic acid in cheeses fluctuated during ripening (Figure 10a,b). Overall, high $\mathrm{Ca}$ and $\mathrm{P}$ cheeses ( $\mathrm{HHH}, \mathrm{HHL}$, HLH, HLL) had higher levels of acetic acid compared with low $\mathrm{Ca}$ and $\mathrm{P}$ cheeses (LHH, LHL, LLH, LLL). In addition, low S/M cheeses (HHL, HLL, LHL, LLL) had a higher acetic acid content compared with high S/M cheeses (HHH, HLH, LHH, LLH). These differences could be related to more extensive lactose fermentation in cheeses with high $\mathrm{Ca}$ and $\mathrm{P}$ and low $\mathrm{S} / \mathrm{M}$ compared with their counterparts.

Lues and Bekker (2002) showed an initial decrease in the concentration of acetic acid, followed by an increase after 3 wk of ripening. St-Gelais et al. (1991) also observed an initial drop in the acetic acid from 2 to 4 mo, followed by a gradual increase up to 6 mo of ripening. Marsili (1985) and McGregor and White (1990) reported acetic acid to increase steadily over the maturation period, which was confirmed by Bouzas et al. (1991), suggesting that acetic acid could be produced from citrate, lactose, or amino acids. In contrast to earlier studies, the irregular changes in acetic acid in our cheeses could be related to the role of acetic acid as an intermediate in biochemical pathways. A similar irregularity in changes in acetic acid content during ripening of pickled white cheeses was also observed by Akalin et al. (2002).

\section{Change in Propanoic Acid over Time}

The propanoic acid concentration during ripening was significantly $(P<0.05)$ affected by $\mathrm{S} / \mathrm{M}$, time, and the interaction of time $\times \mathrm{S} / \mathrm{M}$ (Table 3 ). The propanoic acid content remained stable until 4 wk of ripening (Figure 11a), after which there was a steep increase in propanoic acid content until 48 wk of ripening (Figure 11b). There was about a 10-fold increase in the level of propanoic acid from d 1 to wk 48 in some of the treatments. This increase was higher in low S/M (HHL, HLL, LHL, LLL) than in high S/M (HHH, HLH, LHH, LLH) treatments.

A similar increase in propanoic acid concentration during ripening was observed by others (de Llano et al., 1996; Akalin et al., 2002; Lues and Bekker, 2002). Lues and Bekker (2002) showed an initial decrease in 


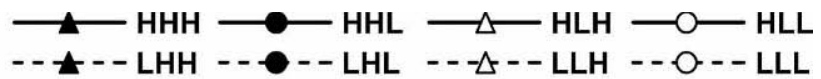

a

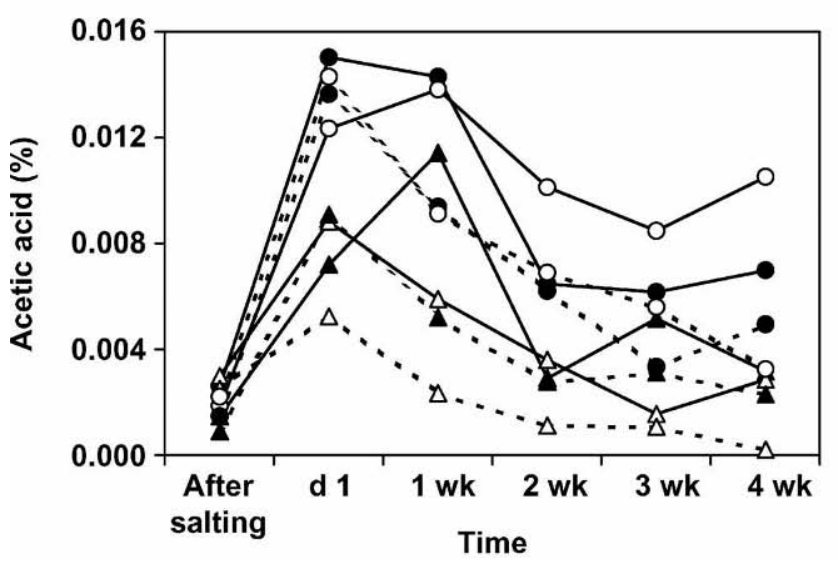

b

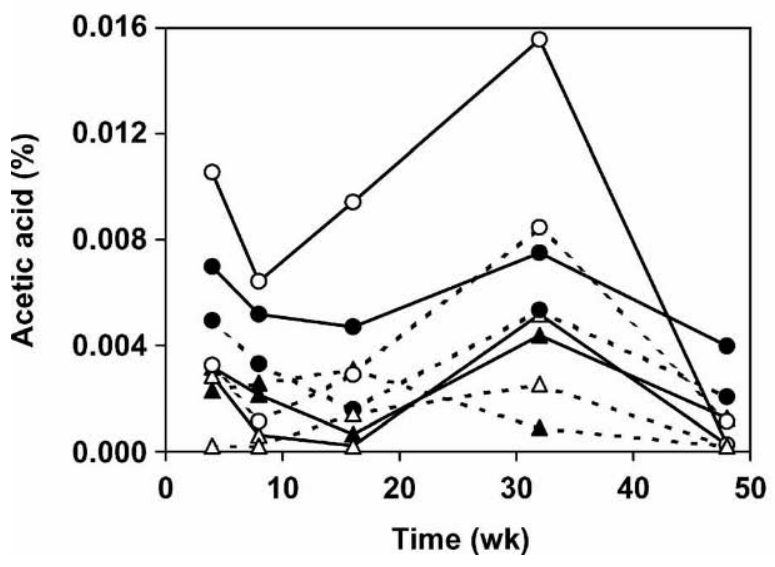

Figure 10. Acetic acid content of cheese during a) the first month of ripening, and b) over 48 wk of extended ripening. $\mathrm{SEM}=1.10 \times$ $10^{-6}$. Treatments: $\mathrm{HHH}=$ high $\mathrm{Ca}$ and $\mathrm{P}$, high lactose, and high saltto-moisture (S/M); HHL = high $\mathrm{Ca}$ and $\mathrm{P}$, high lactose, and low $\mathrm{S} /$ M; HLH = high Ca and P, low lactose, and high S/M; HLL = high $\mathrm{Ca}$ and $\mathrm{P}$, low lactose, and low $\mathrm{S} / \mathrm{M} ; \mathrm{LHH}=$ low $\mathrm{Ca}$ and $\mathrm{P}$, high lactose, and high S/M; LHL = low Ca and P, high lactose, and low $\mathrm{S} / \mathrm{M} ; \mathrm{LLH}=$ low $\mathrm{Ca}$ and $\mathrm{P}$, low lactose, and high $\mathrm{S} / \mathrm{M} ; \mathrm{LLL}=$ low $\mathrm{Ca}$ and $\mathrm{P}$, low lactose, and low S/M.

the concentration of propanoic acid, followed by an increase after $3 \mathrm{wk}$ of ripening. de Llano et al. (1996) observed an increase of propanoic acid in 8-mo-old pickled white cheese to the end of ripening, and explained this increase as the action of esterases and lipases of the starter lactococci and secondary microflora (Stadhouders and Veringa, 1973; Kamaly and Marth, 1989). Propanoic acid has been reported to increase gradually over the maturation period due to the activity of NSLAB (Marsili, 1985; McGregor and White, 1990; St.-Gelais et al., 1991; Bouzas et al., 1991). Propanoic acid fermen-

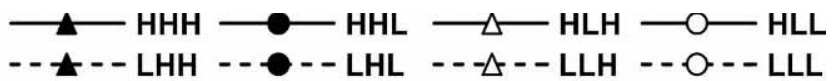

a

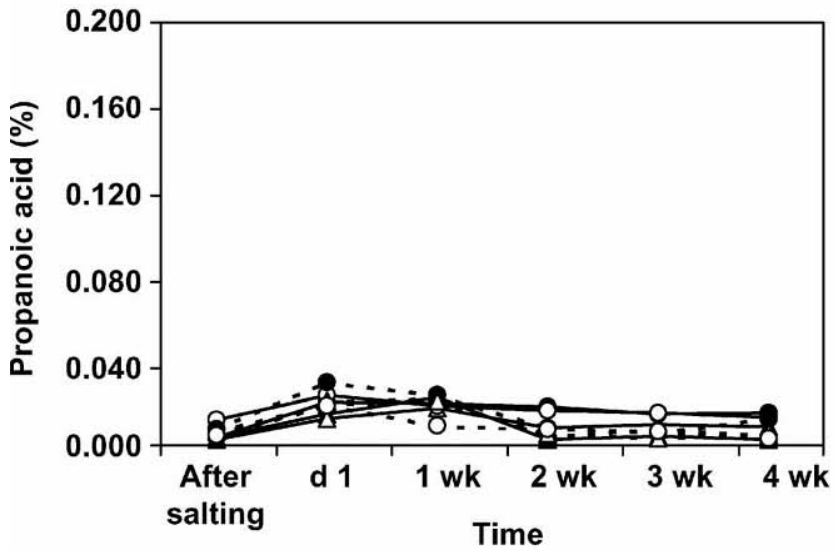

b

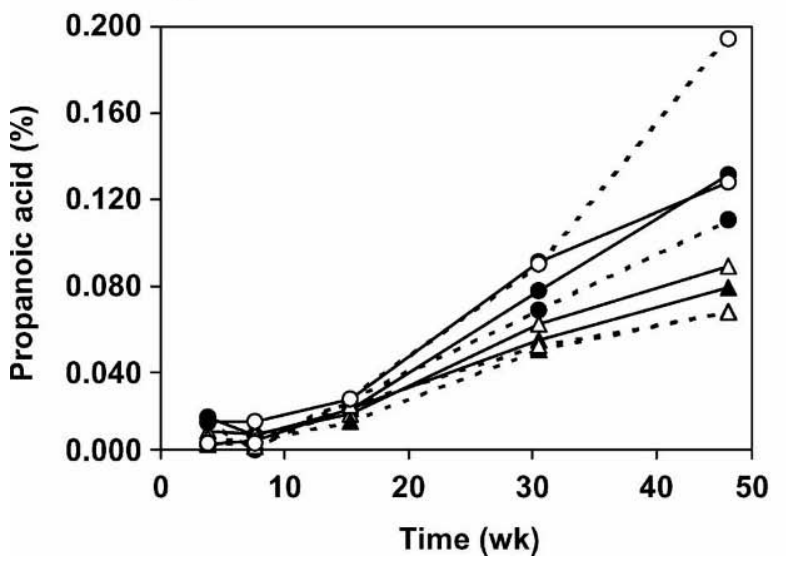

Figure 11. Propanoic acid content of cheese during a) the first month of ripening, and b) over 48 wk of extended ripening. SEM = $1.81 \times 10^{-5}$. Treatments: $\mathrm{HHH}=$ high $\mathrm{Ca}$ and $\mathrm{P}$, high lactose, and high salt-to-moisture (S/M); HHL = high $\mathrm{Ca}$ and $\mathrm{P}$, high lactose, and low $\mathrm{S} / \mathrm{M} ; \mathrm{HLH}=$ high $\mathrm{Ca}$ and $\mathrm{P}$, low lactose, and high $\mathrm{S} / \mathrm{M} ; \mathrm{HLL}=$ high $\mathrm{Ca}$ and $\mathrm{P}$, low lactose, and low $\mathrm{S} / \mathrm{M} ; \mathrm{LHH}=$ low $\mathrm{Ca}$ and $\mathrm{P}$, high lactose, and high S/M; LHL = low Ca and P, high lactose, and low $\mathrm{S} / \mathrm{M} ; \mathrm{LLH}=$ low $\mathrm{Ca}$ and $\mathrm{P}$, low lactose, and high S/M; LLL = low $\mathrm{Ca}$ and $\mathrm{P}$, low lactose, and low $\mathrm{S} / \mathrm{M}$.

tation, proteolysis of side chains of amino acids from casein, and nonspecific esterase activities have also been suggested as sources of propanoic acid during maturation of cheeses (Bouzas et al., 1991; de Llano et al., 1996).

\section{Change in Butanoic Acid over Time}

The concentration of butanoic acid in cheeses during ripening was significantly $(P<0.05)$ influenced by $\mathrm{Ca}$ and $\mathrm{P}$, lactose, $\mathrm{S} / \mathrm{M}$, time, and the interactions of time 


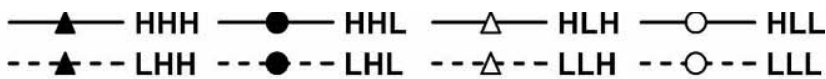

a

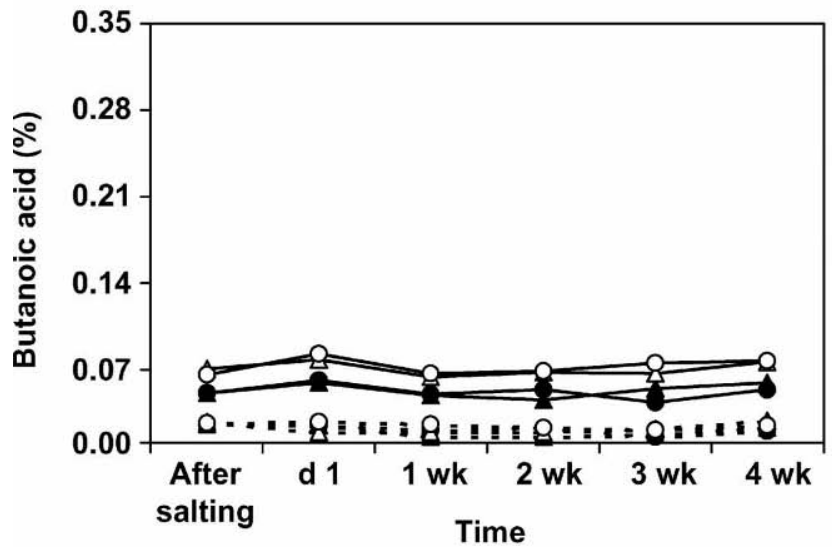

b

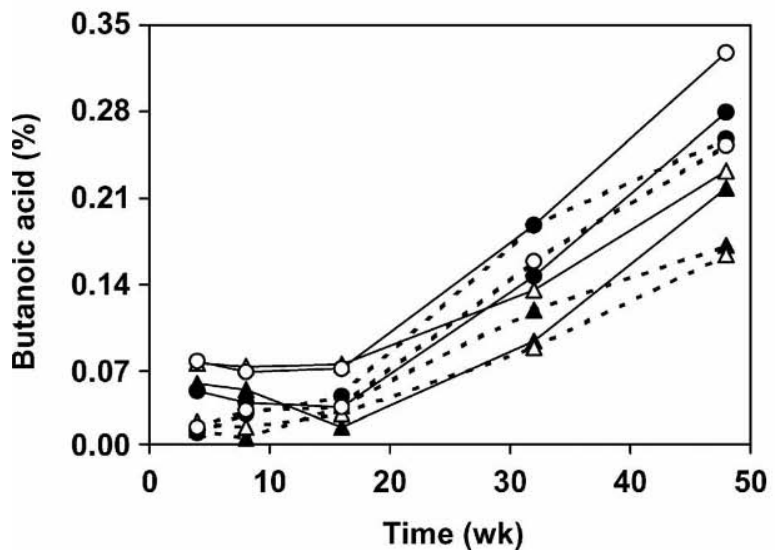

Figure 12. Butanoic acid content of cheese during a) the first month of ripening, and b) over $48 \mathrm{wk}$ of extended ripening. SEM = $5.62 \times 10^{-5}$. Treatments: $\mathrm{HHH}=$ high $\mathrm{Ca}$ and $\mathrm{P}$, high lactose, and high salt-to-moisture $(\mathrm{S} / \mathrm{M}) ; \mathrm{HHL}=$ high $\mathrm{Ca}$ and $\mathrm{P}$, high lactose, and low $\mathrm{S} / \mathrm{M} ; \mathrm{HLH}=$ high $\mathrm{Ca}$ and $\mathrm{P}$, low lactose, and high S/M; HLL = high $\mathrm{Ca}$ and $\mathrm{P}$, low lactose, and low $\mathrm{S} / \mathrm{M} ; \mathrm{LHH}=$ low $\mathrm{Ca}$ and $\mathrm{P}$, high lactose, and high S/M; LHL = low Ca and P, high lactose, and low $\mathrm{S} / \mathrm{M} ; \mathrm{LLH}=$ low $\mathrm{Ca}$ and $\mathrm{P}$, low lactose, and high $\mathrm{S} / \mathrm{M} ; \mathrm{LLL}=$ low $\mathrm{Ca}$ and $\mathrm{P}$, low lactose, and low $\mathrm{S} / \mathrm{M}$.

$\times \mathrm{S} / \mathrm{M}$, time $\times \mathrm{Ca}$ and $\mathrm{P}$, and $\mathrm{Ca}$ and $\mathrm{P} \times$ lactose $($ Table 3 ). The butanoic acid content of cheeses did not change noticeably until 16 wk of ripening (Figure 12a,b). Subsequently, a sharp increase was observed until the end of ripening (Figure 12b). This increase was larger in the low S/M (HHL, HLL, LHL, LLL) vs. high S/M (HHH, $\mathrm{HLH}, \mathrm{LHH}, \mathrm{LLH})$ treatments; and in high $\mathrm{Ca}$ and $\mathrm{P}$ cheeses compared with their low $\mathrm{Ca}$ and $\mathrm{P}$ counterparts (HHH vs. LHH, HHL vs. LHL, HLH vs. LLH, and HLL vs. LLL). In addition, within high $\mathrm{Ca}$ and $\mathrm{P}$ treatments, the low lactose cheeses (HLH, HLL) had higher buta- noic acid compared with high lactose cheeses $(\mathrm{HHH}$, HHL) (Figure 12a). However, at low $\mathrm{Ca}$ and $\mathrm{P}$ levels, there was no difference in butanoic acid content of cheeses with different levels of lactose (Figure 12a).

Akalin et al. (2002) observed an increase in butanoic acid during ripening of pickled white cheeses. St-Gelais et al. (1991) also observed a gradual increase in butanoic acid over a 6-mo maturation period. An increase in butanoic acid content during ripening has been attributed to the action of esterases and lipases of the starter lactococci and secondary microflora (Stadhouders and Veringa, 1973; Kamaly and Marth, 1989; de Llano et al., 1996). Although butanoic acid in cheese could be a result of action of esterases and lipases, lactose as a source of this acid cannot be ignored.

\section{CONCLUSIONS}

Our results indicate that $\mathrm{Ca}$ and $\mathrm{P}$, residual lactose, and $\mathrm{S} / \mathrm{M}$ influence concentration of residual sugars (lactose, galactose) and various short-chain, water-soluble organic acids (citric, orotic, pyruvic, lactic, formic, uric, acetic, propanoic, and butyric acids) during ripening of Cheddar cheese. Although fermentation of residual sugars into acids can influence the $\mathrm{pH}$ of cheese, the absolute concentration and combination of different acids can influence the taste of cheese. Although our study is limited in stating the statistical significance of $\mathrm{Ca}$ and $\mathrm{P}$, residual lactose, and $\mathrm{S} / \mathrm{M}$ on the concentration of water-soluble organic acids in cheese, further studies investigating the influence of these acids on flavor of cheese would be valuable. Identification of the desired balance of organic acids in the water-soluble fraction of cheeses, and modification of the identified factors that influence their formation would help to develop cheeses that exhibit stronger flavor over a shorter ripening time.

\section{ACKNOWLEDGMENTS}

We thank Dairy Management, Inc. (Rosemont, IL) and Midwest Dairy Association (St. Paul, MN) for funding this project.

\section{REFERENCES}

Akalin, A. S., S. Gönç, and Y. Akba. 2002. Variation in organic acids content during ripening of pickled white cheese. J. Dairy Sci. 85:1670-1676.

Bassit, N., N. Cochet, and J. M. Lebeault. 1993. Influence of water activity on Streptococcus diacetylactis metabolism. Appl. Microbiol. Biotechnol. 40:399-401.

Bouzas, J., C. A. Kantt, F. Bodyfelt, and J. A. Torres. 1991. Simultaneous determination of sugars and organic acids in Cheddar cheese by high-performance liquid chromatography. J. Food Sci. 56:276-278. 
Califano, A. N., and A. E. Bevilacqua. 1999. Freezing low-moisture Mozzarella cheese: Changes in organic acid content. Food Chem. 64:193-198.

Cárcoba, R., C. Pin, and A. Rodriguez. 2004. Growth and metabolic behaviour of Lactococcus lactis subsp. lactis IPLA 947 in anaerobic lactose-limited chemostat cultures. Eur. Food Res. Technol. 219:277-281.

Crow, V., B. Curry, and M. Hayes. 2001. The ecology of non-starter lactic acid bacteria (NSLAB) and their use as adjuncts in New Zealand Cheddar. Int. Dairy J. 11:275-283.

de Llano, D. G., A. Rodriguez, and P. Cuesta. 1996. Effect of lactic starter cultures on the organic acid composition of milk and cheese during ripening-analysis by HPLC. J. Appl. Bacteriol. $80: 570-576$

Fagen, H. J., J. B. Stine, and R. V. Hussong. 1952. The identification of reducing sugars in Cheddar cheese during early stages of ripening. J. Dairy Sci. 35:779-782.

Fordyce, A. M., V. L. Crow, and T. D. Thomas. 1984. Regulation of product formation during glucose or lactose limitation in nongrowing cells of Streptococcus lactis. Appl. Environ. Microbiol. 48:332-337.

Fox, P. F., J. A. Lucey, and T. M. Cogan. 1990. Glycolysis and related reactions during cheese manufacture and ripening. Crit. Rev. Food Sci. Nutr. 29:237-253.

Garman, J., T. Coolbear, and J. Smart. 1996. The effect of cations on the hydrolysis of lactose and the transferase reactions catalysed by $\beta$-galactosidase from six strains of lactic acid bacteria. Appl. Microbiol. Biotechnol. 46:22-27.

Huffman, L. M., and T. Kristofferson. 1984. Role of lactose in Cheddar cheese manufacturing and ripening. N.Z. J. Dairy Sci. Technol. 19:151-162.

Hutkins, R. W. 2001. Metabolism of starter cultures. Pages 207-241 in Applied Dairy Microbiology. E. H. Marth and J. L. Steele, ed. Marcel Dekker, Inc., New York, NY.

Kamaly, K. M., and E. H. Marth. 1989. Enzyme activities of lactic streptococci and their role in maturation of cheese: A review. J. Dairy Sci. 72:1945-1966.

Larson, B. L., and H. M. Hegarty. 1979. Orotic acid in milks of various species and commercial dairy products. J. Dairy Sci. 62:16411644.

Lawrence, R. C., H. A. Heap, and J. Gilles. 1984. A controlled approach to cheese technology. J. Dairy Sci. 67:1632-1645.

Liu, S.-Q., R. V. Amundson, P. K. Gopal, R. Holland, and V. L. Crow. 1998. Influence of reduced water activity on lactose metabolism by Lactococcus lactis subsp. cremoris at different $\mathrm{pH}$ values. Appl. Environ. Microbiol. 64:2111-2116.

Lues, J. F. R., and A. C. M. Bekker. 2002. Mathematical expressions for organic acids in early ripening of a Cheddar cheese. J. Food Comp. Anal. 15:11-17.

Marcos, A., M. Alcalá, F. León, J. Fernández-Salguero, and M. A. Esteban. 1981. Water activity and chemical composition of cheese. J. Dairy Sci. 64:622-626.
Marsili, R. T. 1985. Monitoring chemical changes in Cheddar cheese during aging by high-performance liquid chromatography and gas chromatography techniques. J. Dairy Sci. 68:3155-3161.

McGregor, J. U., and C. H. White. 1990. Effect of enzyme treatment and ultrafiltration on the quality of low fat Cheddar cheese. J. Dairy Sci. 73:571-578.

McGugan, W. A., D. B. Emmons, and E. Larmond. 1979. Influence of volatile and nonvolatile fractions on intensity of Cheddar cheese flavor. J. Dairy Sci. 62:398-403.

Nelson, B. K., and D. M. Barbano. 2004. Reduced-fat Cheddar cheese manufactured using a novel fat removal process. J. Dairy Sci. 87:841-853.

Platt, T. B., and E. M. Foster. 1958. Products of glucose metabolism by homofermentative streptococci under anaerobic conditions. J. Bacteriol. 75:453-459.

Sandine, W. E., P. C. Radich, and P. R. Elliker. 1972. Ecology of the lactic streptococci. A review. J. Milk Food Technol. 35:176-185.

SAS Institute. 1990. SAS User's Guide: Statistics, Version 6.0 ed. SAS Inst. Inc., Cary, NC.

Shakeel-Ur-Rehman, D. Waldron, and P. A. Fox. 2004. Effect of modifying lactose concentration in cheese curd on proteolysis and in quality of Cheddar cheese. Int. Dairy J. 14:591-597.

Stadhouders, J., and H. A. Veringa. 1973. Fat hydrolysis by lactic acid bacteria in cheese. Neth. Milk Dairy J. 27:77-91.

St-Gelais, D., G. Doyon, J. R. Rolland, and J. Goulet. 1991. Sugar and organic acid concentrations during ripening of Cheddar cheese-like products. Milchwissenschaft 46:288-291.

Swearingen, P. A., D. J. O'Sullivan, and J. J. Warthesen. 2001. Isolation, characterization, and influence of native, nonstarter lactic acid bacteria on Cheddar cheese quality. J. Dairy Sci. 84:50-59.

Thomas, T. D., D. C. Ellwood, and V. M. C. Longyear. 1979. Change from homo- to heterolactic fermentation by Streptococcus lactis resulting from glucose limitation in anaerobic chemostat cultures. J. Bacteriol. 138:109-117.

Thomas, T. D., and K. N. Pearce. 1981. Influence of salt on lactose fermentation and proteolysis in Cheddar cheese. N.Z. J. Dairy Sci. Technol. 16:253-259.

Turner, K. W., and T. D. Thomas. 1980. Lactose fermentation in Cheddar cheese and the effect of salt. N.Z. J. Dairy Sci. Technol. 15:265-276.

Upreti, P., and L. E. Metzger. 2006. Influence of calcium and phosphorus, lactose, and salt-to-moisture ratio on Cheddar cheese quality: Manufacture and composition. J. Dairy Sci. 89:420-428.

Wang, H., K. A. Baldwin, D. J. O'Sullivan, and L. L. McKay. 2000. Identification of a gene cluster encoding Krebs cycle oxidative enzymes linked to the pyruvate carboxylase gene in Lactococcus lactis ssp. lactis C2. J. Dairy Sci. 83:1912-1918.

Zeppa, G., L. Conterno, and V. Gerbi. 2001. Determination of organic acids, sugars, diacetyl, and acetoin in cheese by high-performance liquid chromatography. J. Agric. Food Chem. 49:2722-2726. 